\title{
THE
}

\section{RICE INSTITUTE}

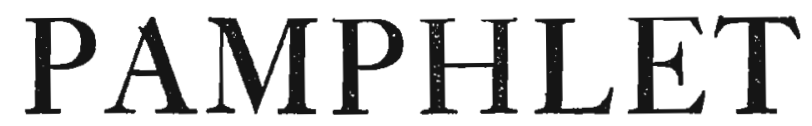

Vol. XLIII January, 1957 No. 4 MONOGRAPH IN PHILOSOPHY

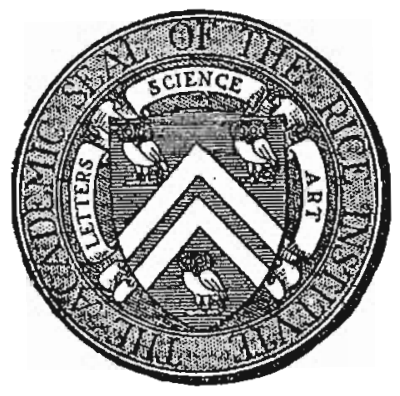

Published by

\section{THE RICE INSTITUTE}

A university of liberal and technical learning founded by William Marsh Rice in the City of Houston, Texas, and dedicated by him to the advancement of Letters, Science, and Art 

THE RICE INSTITUTE PAM PHLET $\begin{array}{lll}\text { Vol. XLIII January, } 1957 & \text { No. } 4\end{array}$

\section{RELIGION AND PHILOSOPHY IN CONTEMPORARY JAPAN}

By

NIELS C. NIELSEN, JR.

J. Newton Rayzor Associate Professor of Philosophy and Religious Thought 



\section{CONTENTS}

Foneword $\ldots \ldots \ldots \ldots \ldots \ldots \ldots \ldots \ldots \ldots$ vii

Chapter I. Post-War Japan $\ldots \ldots \ldots \ldots \ldots \ldots \ldots$

Chapter II. Shinto $\ldots \ldots \ldots \ldots \ldots \ldots \ldots \ldots .20$

Chapter III. Buddhism $\ldots \ldots \ldots \ldots \ldots \ldots \ldots \ldots .41$

Chapter IV. Christianity $\ldots \ldots \ldots \ldots \ldots \ldots \ldots 64$

Chapter V. The New Religtons $\ldots \ldots \ldots \ldots \ldots .82$

Chapter VI. PhLosophy $\ldots \ldots \ldots \ldots \ldots \ldots \ldots \ldots .110$

Notes .......................... 129 



\section{FOREWORD}

THIS MONOGRAPH is a summary of study and research 1 undertaken in Japan during the summer of 1956. Its conclusions have been formulated primarily from personal contacts with priests, professors, and other Japanese. Discussion with religious leaders is not difficult in post-war Japan; every group wishes for the largest possible hearing in the new atmosphere of religious freedom. Occupation policy made for the friendly exchange of ideas, even though it allowed for competition between different sects. At the scholarly level, there is a large literature on philosophy and religion which is almost wholly untranslated. Many of the faculties working in these fields were contacted in the course of this study. Two institutions increased the range of this study immeasurably: the International House of Japan and the International Institute for the Study of Religions in Japan. The contacts which they supplied have been the major sources for this study. I wish to express thanks to Dr. Gordon T. Bowles, Associate Director of the International House, and Mr. Hiroo Mukai of his staff. I am also indebted to the Reverend William P. Woodard, Director of the International Institute for the Study of Religions in Japan.

Niels C. Nietsen, JR. 



\section{POST-WAR JAPAN}

YONTEMPORARY developments in Japanese religion Areflect the drastic changes of the post-war period. The introduction of democracy as well as the end of militarism required far-reaching revisions in the loyalties of the people. Some Westerners expected that freedom would lead at once to new spiritual bases for the common life. However, for the Japanese, the post-war period has been one of singular chaos and moral unrest. The old order, already badly shaken by the war, was attacked frontally in the occupation. Social and intellectual confusion followed the forced meeting of the old and the new. No doubt, the ideological shock of defeat was assuaged by the promulgation of a new, democratic way of life, designed to give genuine self-determination to the country. Yet, the abolition of established authority and discipline led to new stresses in personal existence. For many persons, freedom has had little positive meaning.

It was virtually inevitable that the United States would attempt to impose its forms of political and economic organization on Japan. Most Japanese concede that American wisdom, generosity, and idealișm were often in evidence. Retrospectively, it is apparent that Americans were characterized by a reforming zeal unmatched since the Civil War. ${ }^{1}$ The occupation was a great social experiment embodying changes which the leaders of the United States would not have dared to undertake in their own country. It was not the work of a single person, but supervised by a staff of experts from many different fields. Equality between the sexes, agrarian reform, abolition of peerage, decentraliza- 
tion of civil and educational administration and dissolution of ownership monopolies were long latent needs of the culture. Moreover, this reform would not have been possible on so large a scale had there not been an internal impulse toward democracy in Japanese society itself.

Occupation authorities were most successful in initiating change in the first years following the war. General MacArthur's plan for complete disarmament, subsequently made a part of the new Constitution, belonged to the first early period of American leadership. However, a drastic aboutface in American policy on rearmament, due to the Korean War, subsequently confused Japanese public opinion. The Korean War solved some of Japan's most urgent economic problems, at least temporarily. Yet for most Japanese, it ended the first hopeful period of reform and made them again conscious of the multitude of tensions and pressures of the world power struggle. ${ }^{2}$ In these circumstances, it is not surprising that Japanese traditionalism has again begun to assert itself, as the country is no longer overwhelmed by outside influences. To date, fanatical nationalism has not become strong, but resentment against alien influences is deep-seated.

Japan in most respects is more modern than any other country of the Orient. Western clothes, subways, television, and picture magazines make the visitor feel that this culture is thoroughly Westernized. However, there are significant continuities from the national past at virtually every level of life and thought. The educated Japanese is aware of a long tradition of foreign civilizing influences, dating at least from the introduction of Buddhism and Confucianism in his country. He knows that art and learning were transmitted from China to Japan during many centuries while Western Europe 


\section{Post-War Japan}

was still in the dark ages. He regards America as a very young nation and has mixed feelings about its overwhelming influence in the culture of the post-war period. It is surely a mistake to conclude that the Japanese have not maintained their essential patterns of life and thought even when they appear to react in Western ways. The American conquest with the atomic bomb represents the first time that a foreign power has effectively occupied Japanese soil. The post-war mood has been a paradoxical combination of resignation and determination.

The present importance of Western influences must be weighed against the fact that the Japanese mentality has been profoundly influenced by China as well as India. Although most Japanese historians are careful to point out that there is no universal oriental mind, they insist that cultural assimilation has proceeded in a uniquely Japanese way. This characteristic mode of adaptation continued as the nation opened itself to the West. Government leaders in the last century had the explicit intention of adopting Western technology without occidental ideals or religious orientation. Although they gave careful attention to all types of Western thought, the acceptance of Western ideas in Japan was carefully circumscribed. Conditions have changed since the war, and the increasing influence of Western social and ethical ideals is in evidence, particularly in new democratic practices. It is important to realize that these practices are not deeply rooted in the culture. A most serious choice remains between the major alternatives before the Japanese people, namely, Marxism and Western democracy. It is being postponed, if not resolved, by a return to a traditional Japanese perspective with assimilation continuing in part in the prewar pattern. 
A host of other traditional influences also retard democracy. Following the reopening of Japan to the West, the state officially rejected feudalism and adapted itself to Western culture in the Meiji era, 1868-1912. ${ }^{3}$ The long reign of the Emperor Meiji was dominated by the desire of people and government alike to develop into a modern country. None the less, the spirit of feudalism persists even to the present in Japanese life; indeed, the smallness and overpopulation of the country reinforce its hold on the culture. Paternalism dominates in business and politics as well as in family life. The major part of the Japanese economy is made up of small shops and industries often maintained by a single family. ${ }^{4}$ The technologically efficient enterprises, the large and middle sized establishments equipped for the modern era, employ only twenty percent of the labor force. However, in these industries as well, most Japanese employers do not discharge staff when there is a shortage of work, but spread assignments and earnings among all their employees. Personal contract and obligation are much more important than in the West.

Japan's economic situation remains a difficult one in spite of its remarkable post-war recovery. Land is very scarce. Population pressure perennially serves to intensify other problems. There is a large employment pool even in times of prosperity, and such new production techniques as automation bring special fears. Japan is a prime example of a country which has developed modern industry and good health conditions before the birth rate has leveled off in the pattern of more advanced European nations. Although serious efforts have been made to introduce modern methods from the West to solve the problem of overpopulation, there continue to be nearly as many abortions as births in the country. 
The Japanese attitude in this as in many other areas of life is in part one of fatalism and acceptance. Yet it is a mistake to suppose that the populace will always remain quiescent in spite of the continued pressures for living space.

Marxism is more dangerous in the labor movement than in student groups. Although the latter are often leftist, their members usually abandon the leftist position when they take jobs in industry. Organized labor has grown since the war and probably by and large is a constructive force against a return to the pre-war militarism. Unfortunately, it is subject to strong Communist pressure. Dogmatic Marxism, with rigid distinctions between capitalism and socialism, is very widespread in the Japanese labor movement today. American occupation authorities were in part responsible for the Communist influence in this part of Japanese society. The Japanese unions are divided into two main branches. American officials contributed to the present strength of Marxism by encouraging left-wing rather than right-wing forces over the protests of many of our best friends. The left wing of the labor movement now refuses to support measures to increase productivity unless sources of economic control are modified. The Japanese have an especially lively sense of the international situation-political, economic and social. Communism had its greatest gains in Japan when it swept over China and became a major threat to the West in Korea. ${ }^{5}$

Feudalism remains an even more dominant influence in religion than in economics and expresses itself in a wide diversity of ideas and customs. Feudalistic traits appear in both Shinto, the early primitive Japanese religion, and Buddhism. Both of these religions still contribute significantly to the Japanese mentality. Feudalism is explicit in the Confucian doctrine of filial obligation to ancestors, ruler and 
parents, an ideal which has been developed in an extreme form in Japan. Although ancestor worship was present before the coming of Confucianism, it had its later growth as a result of Chinese influences. In the end, the Confucian position was carried beyond its own traditional limits in Japanese emperor worship. Even Buddhism adapted itself to ancestor worship in the Bon festival, in which the spirits of the deceased are appeased. Some hymns and dances in this festival may have been Shintoist in origin, even though it is now celebrated primarily under Buddhist auspices.

Formalism and ceremony have an indispensable role in both Shinto and Buddhism. Not only practice, but the Japanese attitude itself often defies Western interpretation. Japanese religion is characteristically naturalistic and pantheistic rather than theistic. Moreover, it is not oriented on history as much as Judaism, Christianity and Islam. The Japanese mind is eclectic and inclusive; questions of doctrine are often ignored or minimized. The explicit affirmative or negative of Western thought modes is not accepted. Intuition is stressed more than concept and interpretation. Expression is not alone by word and speech, but by gesture, movement, and repeated act. Basically, Japanese religion is very practical as compared with the speculative religious genius of India. Although there are notable philosophical expressions in the Japanese tradition, they are not concerned primarily with knowledge for its own sake.

This practical attitude contributed to a tradition of state regulation, which in the end has had a singularly debilitating effect on religion. For more than three hundred years, religious practice was strictly supervised by the government for its own purposes. All religions have shown a deep-seated subservience to the state. Their leaders explain that they 


\section{Post-War Japan}

were forced either to become nationalistic or cease to exist. Buddhism was used as a tool to suppress Roman Catholic Christianity for over two hundred years in the Tokugawa era. The ruling classes which forced it to conform to their own secular purposes were essentially Confucian in their loyalties. Government support was withdrawn from Buddhism at the beginning of the Meiji era, and it was persecuted for a brief period. However, Buddhist officials continued to have personal ties with the imperial family until the end of the second world war. Christians also have welcomed state recognition as giving status to their belief and making its practice legitimate.

This legacy of state regulation explains why the contribution of religion to democracy in post-war Japan has not been larger. Government support rendered Shinto and Buddhism spiritually impotent long before the war. Although Buddhism suffered more damage to its prestige in the loss of the war than Christianity, both were affected. On the whole, Buddhists and Christians supported the war effort strongly, although there were sporadic criticisms particularly from the Shin sect of Buddhism, and Christians on occasion refused to pay homage to the Emperor. None effectively broke the traditional pattern of church-state relations. Kishimoto has pointed out that two hundred years of state support destroyed most of the spiritual life of Buddhism. ${ }^{\circ}$ Less than a century of state sponsorship reduced Shinto to an even lower status. Finally, American unofficial support of Christianity during the occupation did little to change the basic norms of Japanese life.

The essentially skeptical, tolerant attitude of the Japanese toward all faiths has been equally as important as state paternalism, in shaping the religious life of the nation. It is 
widely believed that membership in two different groups will increase blessings. Shinto and Buddhism have mingled in Japanese life and thought for more than a thousand years. The problem of religious freedom is different than in the West, because syncretism and tolerance have traditionally gone together. Religious differences have seldom been responsible for warfare except in Nichiren sectarian disputes. Although Buddhist monks have often engaged in political and military struggles, there have been few wars of religion comparable with those in the West. Japanese eclecticism and tolerance reaches even to Christianity. Acceptance of its leading ideas is more difficult because this religion developed its major cultural expressions in the West and has on occasion been persecuted as occidental. Yet many Japanese are willing to say of Christianity that they believe it in part toof

Religious eclecticism also appears in Buddhism itself. As Mahayana, the so-called "larger vehicle," its philosophical idealism differs drastically from the atheistic skepticism of Teravada Southern Buddhism. Mahayana represents a later development in the spirit of Buddha, rather than literal adherence to his teachings. The religion was drastically modified in Northern Asia, accommodating its asceticism to family ideals and accepting a variety of local deities. Japanese Buddhist teachers are proud that their form of the religion does not require the historical Buddha as founder in the same way that Christianity requires Jesus of Nazareth. It is rather made up of timeless insights; S'akyamuni Buddha was only one of many beings who have reached Nirvana. In fact, every man has the possibility of becoming a Bodhisattva or Buddha himself. Intellectually the religion has adapted to the Japanese temperament not only in the Shin and Nichiren sects, but in the very different practices of Zen Buddhism as well. 
Zen Buddhism had its beginnings in China, but came to its own special growth in Japan. In short, there has been an indigenous Japanese development in a variety of different forms of Buddhism. Different schools of thought existed side by side in the early period, even in the same monastery, and generally without religious conflict.

It is important to note that society in Japan is not structured on Buddhist principles as in Siam, Burma, and Ceylon. Christian missionary efforts confront revived, somewhat purified oriental religions in Southeast Asia, notably Teravada Buddhism and Hinduism. Their message and ideology must be answered before Christianity can make significant gains. In Japan, there is no such revival; secular indifference is the main barrier to all religion. Buddhist priests occasionally remark that the Japanese are the most irreligious people in the world. Shinto shrines now function primarily as centers of marriage celebration, and Buddhist temples as sanctuaries for burial rites. Apart from festival and other special celebration, neither religion receives major attention. Participation in their rites and ceremonies has declined notably since the end of the war. The impotence of the high religions, Buddhism and Christianity, has left a religious vacuum in post-war Japan which is being filled by new religious sects on the one hand and by Marxism on the other. It is the New Religions, crude and even superstitious, which have grown most since the end of the war; they are now estimated to have between five and ten million followers.

Hiyane emphasizes that a large amount of fear and superstition is still widespread in Japanese religion. ${ }^{7}$ For example, belief in cursing spirits is basic to much of shrine practice. An old Japanese proverb says, "Unworshipped spirits will reward one with curses." Ancestors, men slain by violence, 
and dead infants are all believed to be wandering about and placing retributive curses upon the living unless they are deified in festival. Religion is motivated much more by fear and dread than by respect. Hiyane concludes, "If Japan had been a part of the continent, exposed to every invading thought; or if the government had not protected the primitive belief in a hothouse; or if the Japanese had taken religion more seriously, then such a primitive mentality would not exist today."

Superstition and traditional loyalty to family and Emperor do not exhaust the spirit of Shinto. The latter has a progressive world-affirming, assimilative character, which is not entirely feudal. Indeed, at least one avowedly Shinto group was persecuted for its pacifism during the war. A number of the New Religions with clear Shinto orientation were dissolved, and their leaders imprisoned. There is little interest in the revival of emperor worship in Japan today. The general consensus of opinion is that this part of traditional Japanese religion is dead forever. None the less, the Emperor has served as an excellent symbol of the continuity and integrity of Japanese life in a period of great cultural crisis.

In spite of widely prevalent syncretism, a number of problems present themselves in the culture as divergent religions live side by side. For example, this is the case in the public schools. Religious training was cared for in part by courses in moral education in the public schools before the war. A strong national consciousness and traditional ethics were enjoined. These courses were abolished by occupation authorities as part of the democratic reforms of the post-war era. Because no suitable substitute has been developed, there is strong sentiment in responsible circles for their reinstatement. On the other hand, moral education encounters very 
strong opposition from the secular forces which were encouraged by the occupation. As educational leaders explain, the changes brought about by the occupation are difficult to modify, as they have become part of the pattern of postwar life.

Religious freedom presents even more difficult problems to democratic leadership. American officials, on their part, were careful not to interfere with Japanese religion, apart from insisting on separation of church and state and the end of emperor worship. At present, there are many reasons to doubt that authentic sentiments for religious liberty were established by their work. The disestablishment of Shinto appeared as a drastically revolutionary change to many devout Japanese. There is little general understanding or acceptance of a free, democratic relation between church and state. Some Shinto and Buddhist leaders now characterize the occupation attempts to challenge long established institutions as cynical and secular. They criticize, in particular, the removal of religion from civic institutions and public life. A major change in the status of religious leaders themselves came about through the occupation land reforms. Temple farm lands, but not forest holdings, were confiscated. At present, there is no large legacy of resentment from this policy.

A number of careful appraisals of American-Japanese relations have traced the changes in the Japanese mood in the post-war era. Among the most discerning is that of Tetsutaro Ariga, Professor of Philosophy at Kyoto University, offered in a paper at the conclusion of the 1956 American Seminar conducted by Tokyo Imperial University. Ariga's judicious characterization of the Japanese temperament is useful in appraising many aspects of the Japanese mind. Ariga refuses 
to speak generally of a conflict between Confucian and Greek thought or even an antithesis between Buddhist and Christian elements of culture. Such appraisal, he argues, is too simple; social change is actually far more complex. The cultural revolution has been very drastic in post-war Japan. Traditional authorities are now defunct in the new era. Japan's most pressing need is for indigenous democratic motivation and expression to displace patriarchy, paternalism and feudalism.

A number of Japanese traits reveal themselves as East and West continue to meet in Japan. Ariga notes first the flexibility of the Japanese mind: He believes that the Japanese mentality should not be characterized as passively receptive. It is not simply imitative but has its own distinctive mode of flexible selectivity. In the past, the Japanese have selected, combined, adapted and assimilated diverse cultural elements from Korea, China, Portugal and Spain. More recently, they have looked to Germany, England, France and America.

Secondly, political and utilitarian motives have often contributed to particular selection. Western science and techniques were accepted for such reasons in the Meiji era; Western civilization was adopted without Christianity and with very little if any concern for democracy. This situation has been somewhat modified in the post-war period. Ariga emphasizes that a variety of Western influences today compete against each other in Japan. Little prejudice remains against Christianity as such, except in rural areas; there is authentic interest in democracy as well as in dialectical materialism and existentialism.

Thirdly, although many different emphases have been taken from Asia, Europe and America, too often virtually nothing has been done to orient them in a logically con- 
sistent system of culture. For example, ideas from Shinto, Buddhism, Nietzsche, Marx, Kierkegaard and Zen Buddhism are often accepted together by the same person with little or no concern about contradictions or inconsistencies. Neither is there a feeling of intolerance towards any particular view. Ariga finds a fourth characteristic of the Japanese temperament in its love of forms. Although this appears particularly in aesthetics, it is not limited to art. The Japanese mentality seeks to discover forms in virtually every area of experience; formalized manners and etiquette develop and find expression in such unique forms as the tea ceremony and flower arrangement. Moreover, "sectarianism" appears in poetry as well as in philosophy and religion. Schools of thought are identified from their founders whose traditions are rigidly established and passed on from generation to generation. Yet, the Japanese intention is to penetrate to the spirit of the master; the goal is both creative and abstract. Forms are not merely external symbols, but are associated with certain mystic qualities. Negatively, Ariga observes that the master-pupil relation is feudalistic, characterized by paternalism and servile deference to authority.

Fundamentally, the Japanese situation has its own distinctive characteristics and can be described only in part by comparison with the West. Characterizations such as "culture lag" are likely to miss the large complexity of response and human variability. Western moral categories or psychology cannot be imposed on it en masse. On the whole, the Japanese attitude is one of patience and resignation, and shows a deep sense of aesthetic harmony as well as community. Skepticism is often held without nihilism. For example, a considerable number of Japanese thinkers are interested in existentialism because it calls attention to the acute personal 
dilemmas of contemporary social life; however, they reject the amoral point of view championed by some European existentialists.

A large problem remains because democracy has too often meant the right to do as one pleased in the disregard of his social responsibility in post-war Japan. Large numbers of people were confused by the drastic social change which accompanied the new freedom from authority. It has been difficult to develop a keen sense of democratic responsibility in a society which remains paternalistic and patriarchical. A long tradition of status ethics predisposes most Japanese to resignation or at most change in one's own self rather than to modification of the environment. Unfortunately, political forces group on the extreme right and left with only a small middle party.

The end of the occupation brought a positive reassertion of the national consciousness and a deliberate return to things Japanese. There is, moreover, growing popular resentment against Japanese dependence on American military and economic resources. Many Japanese regard the presence of American troops in Japan as a continuation of the occupation. However, Americans continue to enjoy remarkable personal popularity because most Japanese distinguish between American foreign policy and individual Americans. A multitude of new practices have been accepted since the end of the war and public opinion in Japan would resist any return to the old order, either to militarism or change in the status of women.

The Japanese attitude toward disarmament is a significant clue to sentiment in the country. There is very strong opposition to the revival of the army or navy because persons who lived through the war believe that it would mean the 
renewed dominance of militarism in the national life. The new Japanese self-defense force is being developed initially in complete isolation from many sections of the populace, notably the intellectuals. It is unfortunate that separation from the universities cuts it off from many of the most dynamic centers of democratic life in Japan. The resentment against all involvements in military affairs is very deep. It appears to have some justification in the widely accepted belief that land armies are outmoded and only a few atomic or hydrogen bombs would be required to destroy Japan.

Educational and intellectual influences came primarily from Germany before the war. These have been superseded in the main by American ideas and ideals. Marxism came to Japan in the 1920 's; its traditions are strong and it continues to have considerable influence in education in spite of pressures against it. Many Japanese are willing to borrow from Communism as much as from any other source; however, a large number of Marxists in Japan are not Russian sympathizers or members of the Communist party. Nationalism is in a measure replacing Marxism as economic conditions improve. The dominant attitude, however, is one of skepticism and relativism without nihilism.

In spite of a multitude of post-war problems, the Japanese universities remain a source of strength in the community. Their leaders boast that they are the freest in the world, even with state support, and they are allowed to elect their own president and professors without government interference. American influence was on the whole constructive and encouraged this tradition of academic freedom, even though occupation policies were in part paternalistic. The Japanese accepted American direction in organizing a society of professors modeled after the American Association of University 
Professors. However, American directives were sometimes resisted. For example, this association of professors successfully defeated occupation attempts to set up the regents system of American state universities. A more serious problem has been brought about by the drastic increase in the number of government universities sponsored by the Americans. Agricultural schools, teachers' colleges, and other small institutions were given full university status in an attempt to bring about a genuinely democratic system of education. Less than eighty percent of college graduates are able to find employment in post-war Japan; the number decreases every year. Moreover, in the difficult economic circumstances of the country, government officials have not known how to abolish any of the new schools. ${ }^{\circ}$

Particularly difficult problems appear in the adaptation of Japanese life to modern technology. Japanese culture does not have roots in the moral and intellectual traditions which prepared the way for the development of modern science. Scientific techniques are more easily assimilated than their cultural context, and effect only one-sided change. In short, modern science was accepted, by and large, without the intellectual tradition of the West. Both positive and negative effects have followed from the fact that the context of culture remained indigenously oriental. A divided mentality often has appeared as the cultural adaptation begun in the Meiji era has been rapidly accelerated in the post-war period. This is particularly the case with respect to democracy and religious freedom; democratic practices were in part imposed on Japan after the war. Ideas which were accepted in the West only after long struggle were suddenly made dominant in Japan.

Professor Seizo Ohe of Nippon University in Tokyo has 
contributed a discerning reappraisal of the role of religion in this highly complex post-war culture. Initially, Ohe denies that Japanese civilization stands at an earlier stage of development than Western Europe:

In short, the Japanese people in their isolated national world at the eastern extremity of the Eurasian continent have experienced, so to speak, the same principal states of cultural development, though on a much smaller scalemas have the European people in their large international world at the western tip of the same continent. ${ }^{10}$

Ohe claims that the Japanese synthesis of the two great Eastern traditions-Indian religion (Buddhism) and Chinese philosophy (Confucianism)-parallels in measure the Western synthesis of Christianity and Hellenism. His comparisons are highly suggestive, even if they do not apply in detail. For example, he points out that Japanese mythology, with its semi-human gods and semi-divine heroes, has a marked similarity to Greco-Roman mythology. Later, monasticism and other worldliness became dominant with the rise of Christianity and Buddhism. In Japan as in the West, the knight and feudal warrior followed the monk. Ohe suggests that Buddhism had a development that parallels the Reformation in the rise of the Pure Land sects in the thirteenth century. However, as in Christianity, the old and new forms of piety continued to exist side by side. Ohe also finds a counterpart to the Renaissance in the naturalistic and humanistic revival of culture in Japan in the latter half of the seventeenth century.

Ohe is particularly concerned about the rise of secularism, both as a common attitude of life and as government policy. He points out that the Emperor's disavowal of divine status was a drastic shock to loyalties which had been nurtured for more than a thousand years in the vague, semi-religious 
sentiments of the people. The mysterious, supernatural, semimystical tradition which had supported "the Japanese soul with a Western intelligence" was smashed in defeat. Subsequently, the restlessness engendered by separation from traditional loyalties has been particularly acute in the postwar generation of young people. Their "rootlessness" presents special problems to education.

To be sure, the majority of Japanese people belong formally to Buddhism, but most of them are merely nominal Buddhists in nearly the same sense as many Frenchmen are nominal Christians; and the Confucian tradition too was already losing its binding force among younger generations before the War, and is losing it more than ever since the end of the War. So the new Japanese national education seems to have no other course than to found itself upon the same humanistic principles as the French national education. ${ }^{11}$

Ohe identifies two different types of democratic tradition in Europe. He describes the French tradition as the most completely secularized of any nation. Ohe does not express opposition to it in principle but only in practice, arguing that its lack of common religious values makes for instability in the body politic. Another type of orientation appears in such Western countries as Germany, Switzerland, Belgium, England and the United States, which he believes still have a

dominant Christian tradition, strong enough to keep the individual souls within a sound social order in spite of all the personal freedoms the law secures them. Probably those who are living within such a tradition are not sufficiently aware of it, but Western democracies as they are now might have been impossible if there had been no such religious traditions as they have still. ${ }^{12}$

Religion has remained a binding force among individuals in the second type of society. Ohe's hypothesis is that the larger religious legacy in countries outside of France gives stability to their respective cultures: 


\section{Post-War Japan}

What I want to suggest with the figurative expression "a slight curve" is a minor return of Japan toward her nationalistic tradition with its inherent ancestor worship which can be used, for the time being at least, as a binding force for individual souls-like the Christian tradition in England and America, in order to prevent the danger of social disintegration. ${ }^{13}$

In principle, however, Ohe favors a democratic society which acknowledges the moral autonomy of its individual members. He believes that this is possible practically only if the religious tradition remains an integrating center. Ohe acknowledges that Japanese religion must make many radical adjustments in the modern era. Yet he believes that Buddhism and Shinto are deeply bound up with traditional Japanese loyalties. The experience of the post-war years has convinced him that Japanese spirituality ought not to abandon its deepest convictions in the midst of war and social upheaval. Its faith, however limited and parochial, makes life somewhat endurable in a time of distress and crisis. Although Ohe makes out a strong case, he does not recognize sufficiently that the possibilities of creative development depend on the religious values dominant in the culture. Ohe minimizes the limitations of Shinto at this point. Nevertheless, he is correct in arguing that Japan ought not to become as secular as some occupation policy implied, especially in view of traditional Japanese patterns of life. Questions about the vitality of religious institutions become of special importance if his view is accepted. 


\section{SHINTO}

HINTO is the most primitive and indigenous of Japanese $\checkmark$ religions, and its practices have expression in a variety of forms. Fundamentally, Shinto is a eudemonistic, worldaffirming religion, which combines nature worship and ancestor worship. All major shrines were formerly controlled by the government. Now, state control has been relinquished and there is a larger measure of autonomy. Household worship as well as the independent sectarian cults show a greater variety of practice. Although the older generation of Shintoists regard their religion as exclusively Japanese, some of its younger devotees wish to adapt it to modernity and make it more universal. It is described by its critics as a nationalistic, essentially undeveloped ethnic religion. However, its modern apologists in the Shinto universities would deny this charge at least in part, asserting that it is a religion of harmony and peace. The number of shrines still extant and the attention given to them make it evident that Shinto still survives as a religious force in Japanese life today.

Shintoists are perennially unconcerned about such problems as the unity of God or the transcendence of the world by some spiritual reality. One of the ablest younger defenders of Shinto at Kokugakuin University in Tokyo, Professor Naofusa Hirai, points out that God himself is often characterized as ineffable in the Western tradition. Shintoism, Hirai argues, emphasizes feeling and practice over concept. Hirai studied in America and refers especially to the ideas of Professor Paul Tillich of Harvard University. Tillich describes God as "Ground and Abyss," but disavows theism. 
Hirai judges that his own Shintoistic position is not too far from Tillich's view, although to be sure Shinto does not take monotheism seriously! According to this interpreter, it is characterized by a sense of ineffability in the context of immanence. It has a sense of mystery without a doctrine of transcendence. Shinto is an attitude and perspective more than a creed. It is, in fact, a social and religious spirit which lives and will continue to live in spite of Buddhist and Christian competition. The religion persists as a sense of immanence, harmony and tradition, and as such is very deep in the Japanese mentality.

The new Japanese Constitution deprived Shinto of its special privileges and state support. Nevertheless, the shrines are again increasing in popularity, and some government leaders appear to regard them as semi-official agencies. Shintoists in 1953 raised sufficient funds to rebuild the Grand Shrine at Ise. In general, Shinto leaders admit that their religion was exploited by militarists and bureaucrats for their own ends in the war period. They urge, however, that it is really a religion of brotherhood and unity. Although they are not as explicitly militaristic as during the war, their sense of national loyalty is very deep.

Two important apologetic works have set forth the postwar position of the religion very clearly. Matsunaga's Shinto and Faith and Nakanishi's The Theory of Shinto present careful philosophical appraisal. Nakanishi's interpretation appears to have at least semi-official approval, as his book was published in a series sponsored by Shrine headquarters.

Matsunaga classifies the non-Shinto religions of Japan into three categories. The religions of vacuity are represented by Hinayana Buddhism. In contrast, Mahayana Buddhism, especially the Pure Land sects, and Christianity are religions of transcendence. Thirdly, religions of immanence such as 
modern scientism are uncritically world-affirming; Matsunaga argues that these, rather than Shinto, are to blame for the war. Scientism, he charges, never really comes to terms with the world in its essential reality, but only represents an attempt to exploit nature. Indeed, none of these three types accepts nature as it is. Such acceptance appears only in Shinto, which alone believes that all things come from the "bosom of mother nature" and are relatives. Such a doctrine, the antithesis of the scientific conquest of nature, is directed toward its love and care.

Matsunaga argues further that Shinto embodies more profound insights than either Western teleology or mechanism. In particular, he criticizes teleology as the modern idol, directing his attack against the idea that purposes are immanent in life. Although he acknowledges that human beings have intentionality, he insists that such is not the case for the universe in general. On the other hand, mechanism is equally to be rejected because it denies freedom and confuses life purpose and life. It is mistaken in disregarding teleology as it appears in man's purposive effort to control nature. Matsunaga believes that both of these positions have their refutation in Shinto, which teaches that life is as old as the universe; it is prior to reason as well as its products such as faith, ideals, purpose, progress, civilization, and causality. Life itself moves on without the purpose which characterizes natural beings and is neither good nor bad but precedes moral values.

Positively, Shinto makes clear that the individual is not a self-sufficient being. Each man owes his life to an indefinite series of ancestors. Neglect of ancestor worship runs the danger of cutting off the present generation from the past national structure of Japan. No sharp line can be drawn between the generations. The dead, like the past, are only 
hidden. In fact, there is no distinct past or present, here or there. Rather, all are joined in a community of life which includes earlier generations and their contemporary descendants. Matsunaga concludes that the rationalist artificially separates himself from such continuity, not understanding that each individual is but a fractional ego.

Nakanishi's distinctions in part parallel those of Matsunaga. He develops his case in The Theory of Shinto as follows: $\mathrm{He}$ first distinguishes realism or the standpoint of Genjitsu, which regards empirical facts alone as real. This position is divided into two types. The first is an objective realism, in particular, the materialism which holds that objects can be verified only by sense perception. Nakanishi argues that such a view is no longer compatible with the facts of science. Practically, it never faces the modern dilemma in which scientific progress has created insoluble social problems rather than leading to new harmonies. Secondly, he distinguishes subjective realism, an idealism or spiritualism which emphasizes the subjective conditions of cognition. Such a view is represented by Kant among others, in the doctrine that reason gives form, order and meaning to data provided by sense perception. Nakanishi argues that subjective realism can allow for deity only as $\mathrm{He}$ is immanent in human reason. Romanticism reacted against this position, emphasizing by contrast each individual's own emotional experience; its interpretation is also unsatisfactory because of the essential uncertainty and instability of this part of man's life. If such a sequence of development is accepted, subjective realism can end only in skepticism and nihilism.

Nakanishi distinguishes transcendentalism or the philosophy of Choetsu from both types of Genjitsu. Choetsu appears particularly in Christianity and Buddhism: Jesus ordered the disciples to renounce all things and follow him; 
S'akyamuni taught the way of renunciation and Nirvana. Both religions are premised on transcendence. There are, of course, significant differences. Christianity teaches existence of an absolute creator, while Buddhism teaches that the transcendent is absolute nothingness. Yet, each religion has a common problem of relating the world to the transcendent, irrespective of how the latter is described. Nakanishi charges that both are philosophically unstable and unreliable; neither has a really adequate way of appraising the scope and values of the present world.

Nakanishi distinguishes the Shinto philosophy of Musubi from both realism and transcendentalism. Its name comes from an old Japanese word which means "to be born and grow." Rather than seeking escape from the world, it attempts to see things just as they are and presupposes no separation of them from their causes. Nakanishi explains his position by use of the Japanese word "mono." In its original sense, this term is an inclusive designation signifying both the actual thing and what lies behind it. Its overtones suggest the Japanese sense of empathy with nature and belief that it has life and feeling. The philosophy of Musubi points to a creative power at work everywhere, producing lilies, plums, and lemons, all from the same soil.

Creative activity is not limited to life in the ordinary sense of the word. Rather, there is a power of becoming which works creatively throughout the universe. Musubi is effective under any circumstances, being characterized by stubborn and persistent creativity. It is without shape, color, extension or hardness, yet it can become all things and all qualities. As the spirit of gentleness, it does the work of assimilation and reconciliation. As the spirit of prosperity, it causes life to multiply and differentiate itself. As related to emperor and ancestor worship, it makes clear the universal signifi- 
cance of the national structure. Nakanishi emphasizes that Musubi in distinction from Choetsu and Genjitsu, points to an all-pervading mysterious power which is fundamental to the Japanese sense of kinship and harmony with both man and nature.

These post-war apologetics must be understood from the background of nearly a century of Shintoist dominance in the religious life of Japan. Modern Shinto has its basis in the drastic changes accomplished under government direction in the Meiji era. Ideologically, it had an important part in preparing for these changes. The reign of the Emperor Meiji, 1868-1912, was a period of national renovation in which Japan opened its gates to the West with the conscious and deliberate intention of learning from the Occident. On the other hand, nationalism and fear of outside influences were perhaps an almost inevitable counterpart to Japan's changed mood. We have noted that both government and people were intent on borrowing technology and organizational techniques from the West without accepting Western religious ideas. Inevitably, however, with the coming of the modern era, there was a reappraisal in the Japanese mind of the nature and meaning of religion.

The government instituted a revival of Shinto at the beginning of the Meiji era. The state required that it separate itself from Buddhism in order to allow for pure Shinto expression. Acceptance of Western European influence was to be accompanied by restoration and renovation of the ancient national cult. Early in 1868, a Department of Shinto was established as a state agency. The Emperor himself led a procession of court nobles to the Hall of Ceremonies to worship all the gods of the Shinto pantheon. In these ceremonies, the Emperor and court subscribed to a Charter Oath which set forth the aims of Meiji rule: the people were to 
renounce Buddhism and accept Shinto as the national religion. Worship and government were to be combined in the same functionaries. In short, there was to be a return to the past as well as an openness to modernity. Japan's own authentic character was to be preserved by the strength derived from its traditional roots in the period of rapid cultural change. State support of Shinto was at once an attack on Buddhism and a counter movement against the growing threat of Western influence in religion. Our later discussion of Buddhism will clarify the reasons for this attack.

Shinto in the Meiji era must be understood from the long tradition of government dominance of religion. For more than two hundred and fifty years, throughout the Tokugawa era, 1615-1868, and even at an earlier period, the state used religion for its own ends. Ieyasu, the first Tokugawa ruler, imposed feudalism on the country following a long period of civil war. Imperial rule was delegated to the Shogun, who held complete authority, granting each individual status only as a member of a particular social class. National life was regulated completely with the intention of maintaining both feudalism and government power. Tokugawa rule led to a rigid society in which the nobility pledged their allegiance to the Shogunate, and the imperial court was powerless. The masses were held in unquestioning obedience by a network of prohibitions which prescribed the details of daily life.

Ieyasu Tokugawa subjected Buddhism to feudalism, placing its religious institutions under state control. Buddhism, a waning spiritual force, was rendered impotent and used as a tool in the suppression of Roman Catholic Christianity. Buddhist temples had been a center of unrest in the sixteenth century, and their warrior monks had often engaged in armed conflict. The Tokugawa leaders destroyed monastic power 


\section{Shinto}

as part of a program of national unification. Subsequently, however, they re-established Buddhism for their own ends. The headquarters of the different sects were controlled by the government. All Japanese were required to belong to a temple as a guarantee against Christian allegiance. In these circumstances, the relation between priests and individual Buddhists became political and economic rather than spiritual. Priests no longer did missionary work, and were very often little more than funeral directors. To be sure, there were some brilliant scholars who managed to produce new ideas in spite of government suppression. There were also devout men who were not prevented by formalism from seeking vital religious experience. By and large, however, Buddhism became increasingly degenerate and subject to public criticism. It was commonly remarked that "the priests are stupid; they confuse the people, waste national resources, and offend morality."

Confucianism was intellectually dominant in the Tokugawa period, and indeed more than Buddhism was the background for Shinto development in the Meiji era. Razan Hayashi, 1583-1657, the official philosopher of Tokugawa, was characteristically Confucian in his general agnosticism. Hayashi was contemptuous of Buddhism even though acknowledging its contribution to political stability. "Buddha," he wrote, "left his prince and deserted his father to seek the true way of life. I know no other way of life than loyalty to one's prince and filial piety." Confucianism had come to Japan even before Buddhism; in particular, it was the NeoConfucianism of the Sung Dynasty in China which flourished during the Tokugawa period.

This philosophy was accepted not only by the ruling class, but influenced the population in general through education and drama. Practically, Confucianism succeeded because it 
received support from the military authority and the feudal institutions of the society. Although it was more friendly to Shinto than Buddhism, it forced both into its feudal structures, minimizing conflict. Hayashi, for example, developed the theory that both religions were the same and differed only in application. Confucianism was theoretically adapted to the needs of the Tokugawa rulers, inasmuch as it joined a hierarchical view of man to a military social structure.

For two and one-half centuries, the Japanese government confined its people within its own national borders and indoctrinated them with Confucian precepts. Confucianism implanted in their minds a tendency toward unquestioning obedience to their superiors. One could not expect to find in Confucianism any development of independent thinking. It did not have the ability to bring change to Tokugawa Japan, though it did develop some fresh approaches within itself, and though it fostered them in other areas of thought. Confucianism's constitutional weakness was that it could not repudiate the policies of the military dictatorship. The intellectual forces which were to lead Japan into the [Meiji] Restoration were to come from outside Confucianism. That is why Confucianism lost its official status during the Restoration.

Yet historical tradition is powerful. The remnants of Confucian influence permeated all thought during Meiji. Its status ethics even assisted State Shinto in establishing the emperor system. Two forces opposed the newly arrived Christianity: the concept of Shinto as a state religion, and the Confucian ethical ideas which it incorporated. ${ }^{3}$

The Shintoism of the Meiji era had its precursors in the National School led by a group of scholars who joined religious and political interests. The two great slogans of Meiji, "The Unity of Worship and Government" and "The Restoration of Imperial Rule" had their basis in its teaching. This school opposed all foreign intellectual influences including Confucianism, Buddhism and Christianity. Politically, its adherents held that the Shogunate usurped power from the rightful ruler, the Emperor.

Shinto scholarship undertook the critical study of ancient 
documents, employing careful philological methods. Norinaga Motoori, 1730-1801, a leading critic of Sung Confucian rationalism, may be cited as example. He wrote: "The gods of Japan are in reality the ancestors of the present Emperor and not mere empty reason." Motoori urged belief in the ancient myths and the personal gods of Japan as against impersonal reason: "The works of the Gods cannot be understood by ordinary human reasoning. Man's intelligence cannot exceed its limitations." Motoori's rejection of both Buddhism and Confucianism, as well as his emphasis on irrational faith, contributed significantly to the Restoration Shinto of the Meiji era.

Atsutane Hirata, 1776-1843, an even more important leader of reform, was influenced in some measure by Christian missionary propaganda from China, although his "Pure Way of the Gods" included other emphases as well. Hirata's doctrine of an all-powerful God and an after-life differ significantly from Motoori's this-worldly Shinto. Hirata held a theory of two opposing deities, one of creation and the other of the after-life, but gave the latter supremacy. Hirata also interpreted the ancient Japanese creation myth in such a way as to make it compatible with Copernican astronomy. As a leader of the new Shinto, he integrated the ancient religious spirit with Western thought. His ideas increased the popular appeal of the religion and enhanced the effectiveness of the government policy.

Hirata's interest was initially religious; neither he nor his followers at first intended the overthrow of the Tokugawa regime. They favored the imperial ancestors over the ancient sages and made the imperial family the ethical ideal of Japanese life on intellectual grounds. Yet, in the end, political consequences were virtually inevitable. Hirata and his followers carried the Confucian theory of reverence for the 
Emperor to the point of a religious fervor, absolutizing the Emperor as a hereditary source of authority and making him the direct object of religious worship. Confucianism had been more static and more closely bound to the past. This new Japanese view was dynamic because it joined religion and ultranationalism.

The Department of Shinto was assigned the task of separating Buddhism and Shinto. Shintoism alone was subsequently to receive official patronage. As a first step, Buddhist statues and ceremonial implements were removed from the imperial palace and placed outside in a separate building. Buddhist priests attached to Shinto shrines were ordered to return to secular life; they were allowed to take up their religious office only when they had been re-ordained as Shinto priests. These repressive measures were not simply an expression of anti-Buddhist feeling; they were as well a protest against the degeneracy of the Buddhist priesthood. Government support for Shinto was explicit. The state took the prerogative of appointing priests for all shrines, from the smallest to the national Grand Shrine at Ise.

Shigenobu Okumo, an official of the Department of Shinto, describes the spirit of the time as follows:

Countries like Spain and Portugal have actually used Christianity to interfere in politics or to steal territory. They may have had similar designs in our country, for which reason everyone opposed both foreign intercourse and Christianity. The desire to continue isolation and to expel the barbarians which was the immediate cause of the Restoration became one more reason for popular distrust of diplomacy and for opposition to Christianity. In addition to the threat of Christianity, Buddhism was daily becoming more corrupt. Its priests and teachers could not lead the people toward a better way of life. The priests had become an additional burden on an already heavy load. For these reasons, people came to believe that neither Christianity nor Buddhism should remain in Japan. The people needed a religion which would not conflict with the basic nature of Japan as it had existed for 
twenty-five hundred years, which would nurture public morality, and which would encourage the people's spirits. What religion had these characteristics? The people, fearful of Christianity, disgusted with Buddhist corruption, and enraged at the excesses of the Shogunate, rallied around Shinto and turned with the force of a great river to the separation of Shinto from Buddhism. . . . The thousands of shrines which had honored the spirits of forefathers and heroes became pure and fitting places for the citizen to express his reverence. At this moment, the government had to proclaim Shinto the national religion. ${ }^{5}$

None the less, serious problems beset all efforts to establish Shinto as a national cult. The ancient Japanese religion was made up in the main of simple ceremonies; theologically, it had accommodated itself to Confucianism and Buddhism. Now, as the major dominant belief, it was required to express itself in carefully defined doctrines and inclusive perspectives. Moreover, its continuing popular appeal was not as large as its supporters had hoped. Okuma ascribes the failure of the government's policy primarily to the fact that Shinto had no outstanding personal leader such as Jesus, Buddha or Mohammed. There were counter-pressures from both abroad and home. For example, Japanese visitors drew large unfriendly crowds in both Belgium and Holland, in mass protests against the persecution of Christians in Japan. In Japan itself, a number of samurai set up an "Office for Investigating Loyalty to the Meiji Government"; its real purpose was subversion rather than support of the regime.

In spite of these difficulties, the government did not abandon its policy but only modified its strategy. It proclaimed the Daikyo or Great Religion based on three principles which were basically Shinto: "1. To embody respect for the gods and love for Japan, 2. To preach heavenly reason' and 'the way of humanity', and 3. To revere the Emperor and obey the authorities." New ethical elements were added for education in the program which was intended 
to "Protect the Country and Aid Religion." Buddhists at first co-operated, but in the end were effective in opposing it after Shinto domination had become clear. Abolition of the Daikyo in 1875 marks nominal recognition by the government that Buddhism could not be suppressed nor its influence fully destroyed. Hori and Toda compare the failure of the government crusade against Buddhism to Napoleon's attack on the Christian Church in Europe. They argue that religion is too personal, too much of the spirit to serve merely political ends. Moreover, it became clear again that Shinto and Buddhism were basically incompatible even in a cultural milieu of Confucian ethics. They are separated as different ways of life as well as religious understanding. The one is immanentistic and eudemonistic and the other transcendental and other-worldly.

Religious freedom was made official in the Constitution of 1889: "Japanese subjects shall, within limits not prejudicial to peace and order and not antagonistic to their duties as subjects, enjoy freedom of religious belief." The same document proclaimed that the Emperor is "sacred and inviolable." The government continued its attempts to establish State Shinto as an ancestor worship cult, even though it declared that "State Shinto is not a religion." Some Shinto priests supported the separation of Shinto as a religion from official ancestor worship because they believed that this arrangement would serve more easily to unify worship and government in this guise. The rites for the ancestors of the imperial household were continued on behalf of the people in general. Hori and Toda comment:

It would seem as if the theory that State Shinto was not a religion should have solved the conflict of religious freedom versus state-supported cult. No matter how cleverly one argues, however, it is impossible not to recognize that Shinto is a religion. This problem of whether State Shinto was a re- 
ligion appeared repeatedly from the middle of Meiji to the end of World War II. It was apparent that to claim that Shinto was not a religion was nothing more than a ruse. Many of the priests lacked confidence at the end of World War II when Shinto had to start once more as a religion because of the contradictions that had stemmed from this subterfuge. ${ }^{6}$

Since the disestablishment of Shinto following the war, the major national shrines have come under the direction of a Shrine Bureau; some shrines have declared their independence and operate separately. Shinto leaders have had difficulty in securing sufficient funds for general activities; income has come primarily from marriage ceremonies. Recruitment of new clergy has also presented a problem, as the vocation has not been as attractive as before the war. With time, some of these difficulties are being overcome and the cultus is again gaining strength. Shrine Shinto combines nature and ancestor worship in a wide variety of practices, with little or no theology.

The thirteen groups of sectarian Shinto which have operated independently of the government since the last century show great diversity. Sectarian Shinto developed in part as a consequence of the government's failure to effect an inclusive State Shinto. All but one of the original thirteen sects centered on a god or some awesome force in nature; most of them were established by laymen and exist independently of the government. Sectarian Shinto illustrates the wide variety of idea and practice which is possible in this religion. Holtom divides the sects into four groups: faith-healing, Confucian, mountain, and purification sects. The diverse character of these sects is best understood from examination of specific denominations.

Konko Kyo is a faith-healing sect which Holtom describes as follows:

Among all the thirteen sects of modern Shinto, Konko Kyo 
has traveled the farthest along the way of the attainment of a free and unified faith, unbound by the restrictions of traditional ceremony and superstition. It repudiates the entire panoply of popular magic and official ritual, rests everything in the creative power of the regenerated attitudes of its believers and teaches that genuine worship must find its inevitable object in the One True God who loves those who trust him in the same way as good parents love their children."

Bunjiro Kawate, the founder of the sect, was born September 29,1814 , in the village of Urami near the Inland Sea. His followers describe him as devout and kind, yet oppressed by a sense of maladjustment to the spirit world. With most other inhabitants of the region, he believed in Konjin, a semidemonic god of Chinese origin. Kawate was taken very ill in 1855 and expected death as a punishment from this god. However, his brother-in-law, who attended him faithfully during this illness, was suddenly seized by a god-possession and given a revelation that Kawate would not die. Subsequently, Kawate himself had a series of revelations which he first ascribed to Konjin, but later came to know as from the One True God of Heaven and Earth. Kawate taught that this God has unmerited love for those who trust him. If man is really sincere toward God, he can become indissolubly united with him in the "mutuality of God and man."

Although Kawate taught mainly by precept and example, he dictated four documents to his followers before his death: "Sacred Admonitions for Direction in the True Way," "An Outline of Instructions in the Way," "Directions Regarding Faith," "The Understanding." All are very brief. Kawate wrote as follows. "No matter how thankfully one may read his rituals and make his purifications, if there is no sincerity within the heart, it is the same as lying to God. The vain making of a big noise by the clapping of hands avails nothing, for even a little sound is heard by God. . . . Pray just as if you were talking to another human being." 
Numerous educational and social activities give expression to this ideal. Fundamentally, the sect emphasizes sincere prayer, spontaneous and natural, as a means of fellowship with God. Although some Shinto deities are accepted in the religion, Konko Kyo's Great Parent God does not appear at all in the classical Shinto documents. In the past, the religion was classified as Shinto partly because it had to fit some form recognized by the state. Holtom quotes the summary of its doctrine by Ikuni Konko, Superintendent Priest at the time of Holtom's study:

Tenchi-Kane-no-Kami, "The God who Gives unity to Heaven and Earth" is the name ascribed to the Great Parent Spirit of the Universe who existed before all time, without beginning and without end. He fills all things and contains all things. The manifest universe, with its infinite variety of form and event, is the outward appearance of the boundless power and goodness of this Great Being. The coming of life into this visible world, the preservation of life in this world, the coming of death and the passing of spirit into the beyond, all the details of food and shelter-not one thing great or small exists or is manifested apart from Him. He is the Great Parent of the true soul of man, and all men, without respect of race or country, wealth or poverty, high or low estate, have unity and brotherhood in him. ${ }^{9}$

A contemporary priest of the sect emphasizes its thisworldly character. ${ }^{10} \mathrm{He}$ points out that its doctrines show no concern for life after death, but only for life in this world. He stresses the founder's teaching that no man need be interested in spiritual salvation if he cannot be saved in this world. Strictly speaking, the sect is neither theistic nor pantheistic; it may be called a kind of polytheism. The founder was not well versed in either Buddhism or Shinto. He has been deified in practice, even though he did not enjoin worship of his own person; the present Superintendent Priest, his lineal descendant, is also regarded as a living deity. However, the religion teaches primarily that each member can and ought to wor- 
ship his own deity. Kawate emphasized that a deity different from that of the shrine can be born in man's own mind by proper training. This deity does not descend from a higher place, but is born in man himself. Moreover, Kawate enjoined each individual to seek harmony with his own deity. Man cannot expect grace if he does nothing. God is not almighty nor to be described as creator, but deity exists for man and man for deity. Serious effort is necessary to make the world better.

The central aim of the sect is to save suffering people. Konko Kyo sent missionaries abroad before the war and now has about ten working in the United States. Its basic message is one of revelation set in a background of folk Shinto. The sect arose in the period when Japanese religious thought was characterized by a strong sense of Shinto as distinct from Buddhism. Laymen have a high place and less authority is given to the priesthood than in many other sects. Konko Kyo claims over six hundred thousand active members beside a million other constituents. Few changes have been required since the war. Konko Kyo's calendar is as follows: Members meet the tenth and twenty-fourth of each month for ritual and preaching. An annual festival, a memorial for its founder, is observed on October 10. The sect's prayer for peace includes outsiders as well as members of the group; divine mercy is invoked for all mankind. December 10 is celebrated as an "all saints day," and April 10 as a spring festival. The second, in particular, includes prayers for a good harvest. August 5, the birthday of the highest priest of the sect, is celebrated with prayers for an enlightened life. The present Superintendent Priest, although elected every five years, has served in the office for sixty-three years. The lowest priesthood requires one year of special training after high school.

Shusei $\mathrm{Ha}$ is a Shinto group nourished by Confucian in- 
spiration. Its founder, Kuniteru Nitta, was born in 1829 on the island of Shikoku. Nitta's allegiance to the Emperor was motivated by the conviction that mere loyalism devoid of religious faith could not be a secure basis for the state. $\mathrm{He}$ was imprisoned for his opposition to the Shogunate before the Meiji Restoration. However, he was honored with court rank by the Emperor before his death.

The ideograms of the name of the sect appear in the mythological sections of the Kojiki, which relates how Izanagi and Izanami "improved" (shuri) and "consolidated" (kosei) or "made secure" the islands of Japan. Eight syllables, Shu-ri Ko-sei Kō-ka Mei-sai, "strengthening, consolidating, glorious, radiant," are repeated in ritualistic chant as an expression of the essential beliefs of the sect and a means of gaining inner tranquility. Nitta's teachings were a combination of Shinto doctrine and Confucian ethics.

Shusei $\mathrm{Ha}$ is polytheistic and enjoins worship of all the "eight hundred myriads of deities" of old Shinto. However, a pantheistic emphasis also appears in Nitta's teaching which derives from the Chinese idea of $T^{\prime} i e n$, Heaven. ${ }^{11}$ Nitta interprets this idea personally. He believed in the spiritual presence of a Supreme Being as the creative will behind all change. This Being manifests himself in the different divinities of Shinto worship as well as in the souls of men. Moreover, man's original perfect divine nature can be repossessed by practicing the virtues of the sect. Nitta taught that Confucianism began in Japan. Although he argued that this philosophy is as old as creation, he believed that the Japanese have shown an innate adaptability to its teaching throughout their history. Very practically, he emphasized that aristocracy and central government are both indispensable to human happiness; they are to be perpetuated in dress and custom.

Shusei $\mathrm{Ha}$ claims that its doctrines conform to biological 
and social evolution. It seeks correction of individual faults through personal initiative, on the one hand, and faithfulness to social proprieties on the other. According to its present leaders, this sect was misunderstood by the Japanese wartime officials and the Western occupation authorities, both of whom regarded it as one of the most militaristic of all the Shinto sects. Shusei $\mathrm{Ha}$ at present represents itself as a peaceful way of life based on the Confucian teaching of filial piety. ${ }^{12}$ Its truth is to be exhibited in a variety of relations with neighbor, husband or wife, children, and friends. In particular, this group stresses the importance of creativity, tracing the idea back to the three deities of creation. According to the Shinto cosmogony, Amatsu-kami (the Deities of Heaven, usually interpreted as the Three Deities of Creation: Ame-no-minaka-nushi, Takami-musubi, and Kami-musubi), ordered Izanagi and Izanami to create the world. Creation is continued by man with the help of divine grace. The sect emphasizes that a "creating deed" is good and a "destroying deed," its negation, is evil.

Besides the three highest deities of creation, attention is given to the evil one, Magatsuhi, who adds evil to creation and prevents its completion. In spite of this doctrine, Shusei $\mathrm{Ha}$ teaches that man's soul is basically good, as given by the deity of Musubi; only bodily desire interrupts the accomplishment of good deeds. Man himself has responsibility for conquering selfish desire and doing away with evil. This is accomplished by reading the Bible of the sect, seventy-seven pages in length, written by the founder, and by prayer. In general, the sect emphasizes ethics rather than mysticism, but it teaches that purification of mind and body cannot be accomplished fully in this life. An annual ceremony is observed in April, the time having been changed from October for the convenience of farmers. Festival prayers are conducted for 
both good harvest and good conduct. The sect claims three hundred churches, sixteen hundred priests and fifty thousand followers. Practically, it is tolerant of Buddhism and still allows Buddhist funerals.

Shinshu Kyo is a purification sect based on the traditional Japanese belief that malevolent spirits will fasten on man if uncleanliness gives them easy entrance into his soul. Its adherents fear pollution, both material and immaterial. The name itself means "Divine-learning Teaching." The sect seeks to embody the sacred way of old Shinto. Ceremonies have priority over words in its "Unspoken Teaching." Shinshu Kyo seeks to bring the immeasurable resources of the unseen world to the support of the prosperity of the nation.

Masamochi Yoshimura, founder of the group, was born in 1839 in the part of Japan which is now designated as "Okayama prefecture." While engaged in meditation on Mount Kurama near Kyoto, he resolved to devote his life to restoration of the cultural forms which were dominant before the coming of Buddhism. Like Nitta, Yoshimura was persecuted for his strong defense of the Throne before the Meiji Restoration. Yoshimura was a student of the Chinese and Japanese classics and wrote commentaries on the Nihongi and the Kojiki. Following three years of austerities and pilgrimages, he claimed to have the revelation which led to the founding of the new sect.

Shinsh $u$ Kyo accepts the god-world of early Shinto, adding to it the spirits of all the rulers of the Imperial line. It teaches that there is an underlying, unitary spiritual reality which is the basis of all created and manifested existence. "The Deity Who is Lord of the Center of Heaven," Ame-no-MinakaNushi-no Kami, is the absolute spiritual source of all things and comprehends the universe and all material objects of the phenomenal world as his "body." Moreover, the Great Life 
of the Universe has a particularly valid manifestation in Japanese history. ${ }^{18}$ Holtom points out that this unitary view is joined to the polytheism of old Shinto by a mediation theory. The primary spiritual character of the universe appears in the great gods. Among the lesser deities, some are good, others evil. Man, in co-operation with the saving powers of the world, can increase the total good in the universe and assist in overcoming the force of the evil spirits. He will thus attain happiness in this life and blessed existence as a kami in the next. Holtom describes the general doctrine of the sect as "esoteric, ceremonial and meditative." "It attempts to harmonize the world of spirit which is religion with the world of material things in which are the affairs of government and social morality." ${ }^{14}$ Its followers are taught to seek the good life in three stages: separation from evil, strengthening of the will to attain consistent progress, and union with God.

The present leaders of this sect emphasize that there is a polarity in creation. Society is not perfect because the divine seed in man is sometimes covered by human selfishness. The imperfect world must be supported and completed by man's own devotion to the good as well as co-operation with the saving powers of the world. The leadership gives priority to religious rather than political interests. Today, the sect claims six hundred churches, two thousand priests and half a million believers. However, this figure requires careful interpretation because members are allowed to belong to other sects. Many other groups allow similar plural membership. 


\section{III}

\section{BUDDHISM}

\section{$\mathrm{J}$}

APANESE Buddhism embodies a rich variety of forms and expressions from its long history. We have noted that it belongs to the Mahayana or Northern branch rather than the Teravada or Southern party. The name Hinayana, "lesser vehicle," a Mahayanist term for Southern Buddhism, is seldom used, as leaders of both schools now seek greater cooperation. Originally, Buddhism came to Japan from Korea and China. Although most schools of Japanese Buddhism are Chinese in background, they also have a history of independent development in their new environment in Japan. There are marked contrasts between the major schools of Buddhism, which are in turn divided into numerous sects. Amida Buddhism, in which the Jodo and Shin sects are the largest, offers salvation simply from calling on the name of Buddha. Zen Buddhism, on the other hand, requires long training in mystical meditation. Nichiren, probably the most indigenously Japanese school, is strongly patriotic if not nationalistic in temperament.

In the narrow sense, a Buddhist temple is simply a sanctuary; however, the term is often used to designate a whole community made up of places of worship, lecture halls, schools, and residences. Japanese Buddhist temples are generally built of wood within an enclosure. The two-story front gate, frequently painted bright red, may be guarded by images of two mythological kings. Burial grounds are located in or near the temple enclosure. More important temples have a large exposed bell which hangs from a simple roof supported by four pillars and is rung by a heavy horizontal striking beam. Many temples include a pagoda as well. Images of 
Buddhas, Bodhisattvas and lesser deities, as well as high priests' images, bedeck the altar of the temple. Lacquer boxes containing scrolls are also kept in the sanctuary. Bells, candles and incense are used in the services in this usually dimly lighted building. Temples are centers for study and individual worship. In general, there is little congregational worship and preaching; the notable exception is the Shin sect, which gives a large place to the preaching ministry. Priestly ritual at festivals as well as special services and funerals depend on the teachings of the school.

Mahayana Buddhism enjoyed the official patronage of the Japanese nobility from the time of its introduction in the country in 552. Its teachings, at first accepted only by the upper classes, were greatly modified as they spread to the masses. Kishimoto and Wakimoto hold that Buddhism is basically antifeudal. ${ }^{1}$ Only when it had become internally weak could it be linked with Confucianism. This view explains why state support in the Tokugawa era was deliberately restrictive. The Tokugawa policy of alleged friendliness to Budhism was reversed in a campaign of Buddhist extermination in the early part of the Meiji era. Shinto leaders such as Hirata wanted to destroy Buddhism outright by force. Others, such as the more moderate members of the Mito School, wished only to eliminate priests who had no genuinely religious function or spirit. The Japanese government's attempt to separate shrines and temples was not at all a reformation in the Western sense, but basically a conservative movement. Yet, in the end, it had important effects on Buddhism.

Persecution led to a Buddhist awakening. Practically, there was a weeding out of priests and purification of the priesthood. More basically, a new consciousness of Buddhism de- 


\section{Buddhism}

veloped. There was not only a reaction against priestly degeneracy, but a desire to study the faith. The Buddhist sense of mission was strongest in the period of maximum government pressure, 1869-1871. "These leaders [of the Buddhist revival] were driven by two motives. One was to protect their faith by righting the evils of the priesthood and consecrating their lives to reviving pure Buddhism. The other was to protect their country from Christianity. For better or worse, this motivation to preserve the nation has been an important characteristic of Japanese Buddhism."

Buddhist Ieaders made a significant contribution to the development of religious freedom, especially from their travel in the West. No doubt they were motivated by desperation as often as by reforming zeal. Yet, they came to recognize that their government's policy of unifying worship and patriotism confused external observance and personal faith. Mokurai Shimajis's "Critique of the Three Doctrines," addressed to the Japanese government, illustrates this opinion:

If the government attempts to enforce a faith based on the founding of the nation and the forefathers of the Imperial Household, it will be using Imperial prestige to constrain men's thinking. At some future time, this will bring sorrow to the Emperor. The ancient past is very distant, and it is impossible to believe in it absolutely. Why should people who have their own faith throw over this faith and follow something in which they do not believe? Even if a person outwardly submits to coercion, grief will build up within him and at sometime in the future will erupt into action. The harm done him at this time will be great in proportion as his previous faith was beneficial. ${ }^{3}$

The Japanese situation, dominated by a polytheistic Shinto and pantheistic Buddhism, was very different from that in the West. Tolerance and syncretism traditionally have gone together while government interference has been in the main on political grounds. It was state pressure, in part in reaction 
against the West, which led Buddhists to conclude that the Japanese government and people had not been sufficiently conscious of religious freedom.

Today, Buddhist leaders admit frankly that some conflict between the various Buddhist sects still continues at both the theoretical and practical level. However, there is considerable co-operation among the more vigorous priests in the Young East, a Buddhist agency which even accepts some support from an American foundation. ${ }^{4}$ This association represents an attempt to adjust to religious freedom and the changed conditions of the post-war era. New organizations of laymen have also appeared since the war, in part as a response to Christian lay activities. The enlarged role of the laymen in the older forms of Buddhism represents a significant change in the Japanese pattern, which must be understood against the background of clerical dominance. The priesthood, now in practice often hereditary, commonly lacks vigor. Except for some rural areas, it cannot be said to have a large hold on the masses. Indeed, the prestige of Buddhism as ritual does not compare with that of Buddhism as philosophy.

The Japanese temperament is predisposed against asceticism as an end in itself, and against philosophical speculation for its own sake; neither asceticism nor speculation have played as large a part in religious life as in India. Even more than in China, the practical rather than the theoretical has been dominant. However, there have been characteristically Japanese forms of piety. The most typical is perhaps the Zen sects which in many ways are the least Buddhist; all Buddhist schools have undergone modification in Japan. The adaptation of Mahayana Buddhism to practices centering on ancestor worship must be emphasized. The Japanese Buddhist temple is above all else a place for the disposal of the dead. In accommodating itself to the Japanese temperament, 
Buddhism has often become superstitious as well as nationalistic.

There was a significant change in the situation of the clergy with the confiscation of temple farm lands in the MacArthur land-reform program. Priests were allowed to keep only the land which they could farm themselves. Some of the younger priests argue that this change will eventually give Buddhism new vigor, as the clergy will again have to live and work among the people; this judgment is probably somewhat optimistic. Unfortunately, Buddhism is not a vital, moving spiritual force in Japan today, even though a Buddhist attitude persists from long centuries of national life. Buddhism receives recognition in festival celebration as well as in funeral service; yet the temple is primarily a place of priestly residence and ritual observance. Of course, any change from Buddhism to another religion would represent a basic alteration in the Japanese family system. In particular, it would require change in the mode and place of burial, which most Japanese, particularly those in the country, are unwilling to accept. Disposal of the body is by cremation, but the ashes are kept in the temple grounds. The institutional power of Buddhism remains strong; many of the new cults allow their adherents to keep their ancient funeral customs.

Buddhism has accepted the eclecticism of the Japanese religious consciousness and accommodated itself to Shinto. There has been an interchange between the two religions and in periods of its dominance, Buddhism has nearly absorbed the indigenous Japanese religion. In practice, it has adjusted to other religions more easily than to the ideas of modern science. Western-educated Japanese commonly remark that Buddhist priests live in the past, and indeed this is probably the dominant attitude among them. Their mood is one of resignation and patience, a consciousness of many centuries, 
but witn no real sense of urgency in history. Describing the skepticism and almost complete lack of interest in religion among young people, a priest is likely to say that all Japanese give more attention to religion in later life. Moreover, the skepticism inherent in Buddhism itself remains in spite of all Mahayana development. To be sure, the large disdain of all positive religious affirmation among students and intellectuals must be explained in part from the influence of Confucianism. Yet, this disdain also reflects a major weakness in the Japanese temperament. Buddhism assuredly developed no strong social ethic in Japan. Virtually the only persons following the pattern of life advocated by S'akyamuni Buddha himself are the Buddhist nuns.

Monasticism is less strictly enforced in the Northern than the Southern schools of Buddhism, and a kind of unofficial hereditary priesthood has grown up since the priests were allowed to marry in the last century. Shin priests have married since a much earlier date. Bunce reports that most sects have three orders of priests with rank and one without rank. However, there is no general uniformity among the different sects today. As an example, Bunce has worked out a description of the ranks of the Shingon sect, comparing them with Roman Catholic usage:

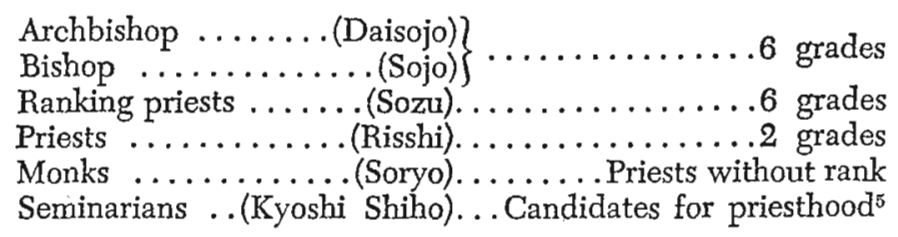

There is no single fixed canon of Scripture among Mahayana Buddhist groups. Indeed, S'akyamuni Buddha's teachings have been preserved in a variety of languages and forms. The Pali canon of the Teravada school is often regarded as earlier and more authentic than the later Sanskrit literature 
of Mahayana Buddhism. Japanese scholars urge, however, that the problem of primitive Buddhism is more complex and cannot be settled simply by deference to Teravada teaching. The relation of Mahayana and Teravada interpretation has received special attention, particularly in the new attempts at co-operation in the World Fellowship of Buddhists.

Sasumu Yamaguchi has recently explained the Mahayana position in detail in The Path of the Buddha. ${ }^{6}$ Buddhists agree, he argues, on their master's teaching of the Four Noble Truths which make clear the cause of suffering and the way of its extinction. Birth, decay and death can all be traced back to a basic chain of ignorance. Ignorance gives rise to will, and will to action, which in turn produces consciousness. Yamaguchi describes the twelve links in the chain of causation as basic insights of the religion; the chain is made up of ignorance, will-to-action, consciousness, psycho-physical existence, six organs of sense, contact of subject and object, feeling, desire, grasping, existence, birth, and decay and death. Buddha taught that the individual will not be afflicted by suffering if he realizes the vanity of the existence of things. He will know that all things are interdependent, not independent, and as such are transient and void.

Yamaguchi holds that Buddhism became formal in doctrine as disciples attempted to arrange and transmit the master's teaching. The order of monastics grew and added many new rules of discipline. Subsequently, the religion divided into two schools, the Sthaviravadins or conservatives and the Mahasanghikas or progressives. This basic schism, which occurred before the death of the Emperor Asoka, dominated the two centuries which followed his reign. Both conservatives and liberals devoted their primary attention to expounding and explaining the logic of Buddha's words. Yamaguchi writes: "At no other time in its history was Buddhism so di- 
vergent in its interpretation as at this period." The conservatives generally argued that everything exists. "The existing things were classified as seventy-five dharmas, which were divided into five categories-form, mind, function of mind, action not connected with the mind, and the non-phenomenal element." The conservatives gave their major efforts to explaining the essential characteristics of the seventy-five dharmas.

According to Yamaguchi, the fundamental principles of Mahayanism were established in refutation of this scholasticism. The Prajnaparamita Sutras, in particular, represent a significant major effort to restore the original form of Buddhism after it had degenerated into conflicting interpretations of nihilism and realism. Prajnaparamita itself means "wisdom that has attained the Other World"; it has attained the World of Awakening by destroying illusions. The Prajnaparamita Sutras deny completely the substantiality of all conceptions including those of Buddha and Bodhisattva; they teach that voidness and incomprehensibility are the true wisdom. This is the truth of primitive Buddhism. Yamaguchi quotes Nagarjuna's summary of their ideas as follows:

The perfect Buddha,

The foremost of all teachers I salute;

He has proclaimed

The Principle of (Universal) Relativity;

'Tis like blissful (Nirvana)

Quiescence of Plurality

There nothing disappears,

Nor anything appears,

Nothing has an end,

Nor is there anything eternal,

Nothing is identical (with itself),

Nor is there anything differentiated;

Nothing moves,

Neither hither nor thither, ...7

Although Mahayana Buddhism includes a wide variety of 
ideas, its apologists claim a basic unity. Japanese Buddhist interpreters argue that the division of sects was forced by later government registration and is in part artificial. The Mahayanists hold that the ideal of Enlightenment unites all schools; all Buddhists seek this common end. Buddha himself is said to have allowed for four thousand different ways of enlightenment. The eternal truth of Buddhism is not limited to any single historical epoch or point of time. Rather, the Mahayana schools are free to range through the diverse aspects of Buddhist truth; in the main, their ideas supplement each other. We should not be surprised to find an alert Jodo priest studying meditation at a Zen monastery! Moreover, the teachers of the Northern school have not limited themselves to merely psychological interpretation as in Teravada. Rather, disavowing literalism, they have developed Buddha's perspectives in their fullness and given them a metaphysical as well as a spiritual meaning. Professor Masunaga, for example, uses ideas from a number of different schools of Buddhism in explaining the Mahayana doctrine of salvation: Shin teaching stresses the sinfulness of all men, insisting that each man is a sinner worthy of hell. ${ }^{8}$ Zen, on the other hand, is premised on the intrinsic soundness of human nature and teaches that man deserves and will receive salvation. According to Masunaga, these views form a necessary composite picture.

Japanese Buddhism, as optimistic and world-affirming, is in conscious and deliberate conflict with much of Teravada Buddhism and Hinduism. To be sure, it teaches that the phenomenal world is not the ultimate; yet, it seeks to balance withdrawal and return. In particular, it emphasizes world affirmation even in world denial. Professor Nagao of Kyoto University summarizes the Buddhist position as follows: "There is always a deep negation but it does not penetrate all reality." $\mathrm{He}$ stresses the positive affirmation of the Bodhisat- 
tva ideal that every man in time can become a Buddha. This positive concern appears in the Mahayana ethics of outgoing benevolence, peace and compassion. Shinto, of course, does not share Buddhist negation, but it also has no sense of transcendence.

The skeptical side of Buddhism, dominant in its Southern Teravada form as denial of God and the soul, is not emphasized in Japanese Buddhism. Rather, modern Mahayana interpretations show striking similarities with Western idealism; philosophically, they often borrow their categories from Hegelianism. Buddhist scholars have also become interested in modern existentialism, although they generally seek to encompass its nihilistic emphasis in an idealistic synthesis. A number of competent Buddhist scholars in Japan teach in Christian schools. Their critique of Western philosophy and religion is often discerning.

The contemporary apologetic for Buddhism has been developed in most detail by the Shin and Zen sects. Their teachers argue that Buddhism is a religion of transcendence, but not of absolute transcendence in the Christian sense. Fundamentally, it finds reality beyond the phenomenal world, turning aside from the world of space, time and sense to more ultimate reality. However, it does not ignore the space-time world completely. Buddhist interpreters emphasize the parallels between Heidegger's existential "Nothing" and the Buddhist idea of negation. Although conceding that Heidegger's background is Western, they believe that his later works in particular lean toward Buddhism. In criticism, they insist that his "Nothing" is not drastic enough and in consequence is not negated again in a more positive fullness. This Buddhist view, although giving priority to negation, is somewhat similar to that of many Christian theologians. Its defenders hold 
that existential fear and anguish can be resolved in a religious doctrine of deliverance and enlightenment.

In developing their own position, Buddhist expositors insist that true nothingness is true being; they stress, in particular, the identity of contradictions. Centering their primary attention on non-being, they claim that the true self is the notself. None the less, they teach that their philosophy is an intelligible one, which affirms the world by denying it and identifies the proper self as the not-self. Their peculiar descriptive phrases express the basic conviction that reality does not find its fullness in a transcendent God. Rather, the most real is ineffable and indescribable. Although it can be talked about in measure, exact logic is not the appropriate tool for its description. Zen apologists speak in paradoxes and contradictions to the point of meaninglessness and apathy for the uninitiated. Basically, however, they wish to direct attention to pure experience and give priority to insight purified by meditation in the life of the spirit. They sometimes describe William James as a sensitive interpreter, who would have appreciated their orientation.

The doctrine of negation and transcendence has a singularly drastic expression in the Zen school; in this form, it can be clearly distinguished from Vedanta. Professor Masunaga, for example, denies all cosmology and insists as well that this view transcends both optimism and pessimism. He will not allow description of Zen as mysticism; such a definition, he urges, is "too spread out." Zen as a living principle is more concentrated and cannot be formulated apart from daily life. Unlike some other forms of Buddhism, it shows a large love of nature, yet it is beyond pantheism. In its dynamic pragmatic character, it teaches in particular that symbol is not reality. Zen accepts with other schools of Buddhism that the 
universe is created by man; religion is at most an appendix. Zeal and freedom are made possible by the recognition that existence and morality are autonomous.

Zen teachers emphasize that it is possible and appropriate to speak of religion and devotion without God. They describe spiritual reality as absolute being and non-being, and teach that it exists only at the human level. Moreover, it cannot be delimited by mere logical categories; in fact, according to Zen it defies them. In short, reality is free of the conceptual and must be viewed practically. In the last analysis, we must be silent about it even as we share in it. Most Mahayana philosophers claim that time has no reality apart from or outside of human existence, although its essential character is not at once self-evident at this level. They believe that reality cannot be described in simply static or dynamic terms, but transcends both. It is important to recognize the moral integrity of the Zen teachers and the persistence in strength of their doctrines, in appraising this position. Moreover, they continue to be interested in the serious expression of their ideas in philosophical language, even as they do not lose their profound sense of the transitoriness of the world and the illusory character of evil.

The Zen masters are emphatic that egocentricity must be destroyed. ${ }^{10}$ Only evil can follow from the illusion that the self is bounded by its own ideas or the usual distinctions of thought. Rather, the true self transcends all logical forms and space and time. The real self is beyond the human self, even as reality has no limits. Ultimate knowledge of the self is available to the individual in a variety of ways; there are many paths to enlightenment. Teachers can serve only as guides; finally, each individual must instruct himself. His own Buddha nature must be realized and come to control. Zen meditation is characteristically severe and strenuous. The 
candidate may read Koans and meditate even upon nonsense sentences. It is important to note that these teachings show relatively little concern for the idea of karma as compared with Hinayana Buddhism and Hinduism. The principle is recognized as the causality which derives from past events and lifetimes. However, the self is not believed to be inexorably bound to its previous history, but can inject new concerns and causality into it.

The Buddhist point of view is most defensible if it is understood as dynamic in character. Fundamentally it is limited to mental states and does not deal with the self per se, inasmuch as the latter is beyond all specification. Evil, although very deep-seated and sometimes designated as sin, is essentially ignorance. Salvation must come from one's own being. A theistic tendency in Buddhist devotion appears particularly in Amidaism. Shin teachers assure their followers that there is a love in the universe great enough to take care of the salvation of all mankind. The eternal Buddha principle is personified and salvation is believed to come through faith in Buddha. This Amidaism, with its doctrine of a personal savior, may be explained in part from the rich multiplicity of Buddhist thought. Although there are significant parallels with Luther's doctrine of justification by faith, the theistic tendency is not expanded to the doctrine of a creator God. The Judeo-Christian doctrine of creation, the claim that salvation must come from outside man's own self, and indeed Western personalism are all generally denied.

Professor Masunaga holds that Buddhism does not believe in the salvation of any single individual apart from the salvation of all mankind. It does not, he urges, look for the salvation of one man in complete separation from that of his fellows. Moreover, he believes that the idea of personal immortality is too anthropomorphic; selflessness must mean the 
end of personal identity. Masunaga will not accept the classification of Buddhism as idealism; its perspectives, he believes, are more dynamic and more genuinely growing than nineteenth century European idealism; they are also more sensitive to evil. Buddhism looks for nothing outside of existence; time and existence are the same even though they have a special qualitative character. Masanagua's perspective is clearly Mahayana, inasmuch as he argues that Buddha, while embodying his teachings, does not exhaust the truth of Buddhism.

Many Japanese scholars distinguish between Buddhism as philosophy and as religion. They argue that Buddha's ideas were degraded when they were made a popular religion. Compromise with the native folk religion came about as Buddhism was regarded as a religion. However we may evaluate these claims, it is clear that Buddhism has been and remains a philosophically productive perspective. A long tradition from the time Buddhism was first taught in Japan, regards it as a philosophy for the truly wise. We have noted that it remained among the upper classes for a number of centuries. The large popular movements came later. Some compromise appears in the claim that Amidaism, belief in a personal Buddha, belongs to practice but not reflection; the personal side is for devotion only.

The profundity of Buddhist reflection makes clear that the ideas of the religion have entered deeply into the Japanese temperament. A number of Westerners have been attracted to Japanese Buddhism, in part by its mysticism and devotion and in part by its disavowal of the problems of theodicy. To be Japanese culturally is to be a Buddhist. There are cases of Japanese who became Communists, but subsequently gave up Marxism through reading the Buddhist Scriptures. Impressed by their purity and insight, they became aware of a 
spirituality which Marxism could never supply. Such awareness is still very deep in the Japanese temperament in spite of secularism.

There are many parallels between Mahayana Buddhism and Vedanta Hinduism. Japanese scholars suggest that Vedanta was probably influenced by the Mahayana Buddhism which preceded it in India. Buddhist teachers point out that Zen is closest to Yoga practice. From their point of view, Yoga may be considered, in some respects, a form of Zen. Comparison of the historical differences between Buddhism and Hinduism raises many complex problems. Philosophically, Buddhists urge that their doctrine is more faithfully existential and true to experience than Hinduism. It does not presuppose the fullness of the self initially as in Vedanta, but knows it only from life and experience in time. Buddhists claim that they take negation and transcendence more seriously than Hinduism. Buddhism regards doubt as necessary to enlightenment and the awakening of the true self, on the one hand. On the other hand, it holds that true reality is beyond all limits of the relative and the absolute, transcending not only the intelligible world but all religious realms as well.

Buddhist sectarianism rivals that of Christian groups. On the one hand, the diversity of belief and practice among the different Buddhist schools indicates the rich, many-sidedness of the religion, embodying heritances from the different stages in its history. On the other hand, it also makes clear the limitations of cultus and ideas as they have developed in Japan. Although all of the differences between the sects are not of importance in discussion with the West, the entire development is probably best appraised historically.

Mahayana Buddhism came to Japan in 552 A.D., but sectarian differences were not widespread for nearly three 
quarters of a century. Buddhist missionaries appear to have believed that the Japanese were not ready for the detailed metaphysical distinctions of Chinese sectarian speculations. ${ }^{11}$ Consequently, they refrained from teaching about them until the religion took root in the country. The first Japanese division into schools appeared between 625 and 754 in the Nara sects; at present, these groups are mainly of historical interest. Sanron, Jojitsu, and Kusha have died out altogether; Hosso, Kegon, and Ritsu have only about one hundred thousand remaining followers. The influence of the Nara sects has been limited in the main to the noble classes, and they probably would not have survived apart from government patronage in the past.

By 794, Buddhism had become so corrupted by political intrigue and the luxury of the court that the Emperor Kwammu moved the capital from Nara to Kyoto. He wished to replace the already corrupted forms of the religion with new and purer ones as well as to free it from political influence. The Emperor sent two priests, Saicho and Kukai, to China to re-study the faith; these men in turn had a large influence on the future of religion in Japan. Saicho founded the Tendai sect while Kukai began Shingon, the two traditions which together dominated the spiritual life of Japan for a number of centuries. The leader of Tendai, known posthumously as Dengyo Daishi, spread his ideas from a small training center on Mount Hiei. This community later increased in size and exerted a very large influence on Japanese life. Saicho's position was eclectic and included almost all of the doctrines of Chinese Buddhism. Esoteric mysteries, abstract contemplation, and faith in the saving grace of Buddha, were accepted together, although the method of salvation was left in the main to the individual. Saicho gave primacy to the Lotus Sutra, which he believed to be the 
greatest of all Buddhist scriptures. He taught that its truth, like that of all Buddhist doctrines, can be known fully only by meditation.

The modern Tendai school, in agreement with Saicho, emphasizes that man has a middle place between the heights of illumination and the depths of vileness. Each individual person rises or falls according to his faith in Buddha. This school teaches that there are three forms of existence, namely, the void, the temporary, and the middle. The third, the middle, is described as absolute existence, all other types being dependent on it. Enlightenment is possible only when the individual sees all three forms of existence in their perfect relationship. Each man may enter on the path of illumination by making certain vows to Buddha. Meditation upon the truth of this teacher makes clear the relation between the individual and the universal self, as Buddha unites both in himself. Although incarnate in human life, he has ontological identity with universal being.

Tendai had its maximum influence in the ninth and tenth centuries. Today, it remains an unusually fine field for historical research because of the many-sidedness of its teachings. At present, it is estimated to have approximately a million followers, in the main from the upper classes. Characteristically, it has had significant social concerns. Members are enjoined to seek realization of the Buddhist ideal by promoting spiritual and material improvements in both individual life and that of the nation. They are to seek salvation not only for themselves but for others as well.

Kukai, the founder of Shingon, was known posthumously as Kobo Daishi. This monk returned from China a year later than Saicho, teaching a pantheistic mysticism. According to Kukai, the whole universe is the body of the cosmic Buddha Dainichi. Every grain of dust partakes of Buddha's spiritual 
life, since his body is the whole of material existence. An understanding of the secrets of reality is enhanced by performing mystical signs with the fingers. Recitation of magical formulae and meditation leads to the enlightened understanding that all phenomena are activities of Buddha's body, voice, and mind. Practice of the secrets of the school not only enables a person to become identical with Buddha in this life; an esoterically adept individual can acquire wealth, find recovery from disease and bring about good harvests.

Kukai's incarnation theory paved the way for the amalgamation of Buddhism and Shinto. Unification with Shinto on the basis of an all-embracing Buddha helped to popularize the new religion. An attempt had been made earlier at Nara to identfiy the native Shinto gods with Buddhist deities. However, Kukai's pantheon of numberless Buddhas, Bodhisattvas as well as demons and angels, made for an easier eclecticism. Shingon means "magic formula" in Sanskrit, and the esoteric practices which have continued to persist through all secetarian divisions of the school have had wide influence beyond it. Its emphasis on sacred functions of body such as speech and mind, complicated manipulation of the hands and fingers, incantation of mystical formulae, and, most of all, its promise of worldly profit, have long appealed to the common people. The mandala used in Chinese Buddhism was first employed extensively in Japan by Kukai. This pictorial device, a graphic representation of the universe explaining the Buddhist pantheon, is used by most Japanese Buddhist groups today. Two pictures portray "the ideal" and "the dynamic" in the universe. The bodily postures and movements of the hands and fingers employed in mystic Shingon rituals are also depicted.

Amidaism had some emphasis in the teachings of Saicho in the ninth century. However, it did not come into its own until 
the twelfth century, when it became the most important form of Japanese Buddhism. Eliot suggests that Amidaism began under the influence of Hinduism in the Northwest part of India, not long before the beginning of the Christian era. ${ }^{12}$ Subsequently, it came to make up about a third of the Mahayana literature. This form of Buddhism is founded on the tradition that Amida, a Bodhisattva, vowed to refuse supreme enlightenment, unless he could share his merit with all people who meditate on him. In short, he wished enlightenment for all mankind and not simply for himself. Amida is believed to have later founded a Western paradise, called "the pure land" where he preaches "the law of Buddha" to the blessed. Bunce argues that there is no historical evidence that Buddha Amida was a historical person; he is only an abstraction personifying infinite benevolence. ${ }^{13}$

The Jodo Pure Land sect, founded by Honen, 1132-1212, claims to conform to the original teachings of Amida Buddha. Honen originally studied for twenty years at Tendai institutions on Mount Hiei. His later Jodo teaching was that mere recitation of the words, "adoration to the lord of boundless light and infinite life," accompanied by faith, would give assurance of rebirth in "the pure land." Indeed, repetition of this phrase is the chief end of life, all other activities being secondary to its utterance. Although Amidaism encountered vigorous opposition, in the end it prevailed in the popular mind.

Honen and his chief disciple, Shinran, 1173-1262, were both exiled in 1207. The ban against them was lifted in 1211, but Shinran did not return to the capital until 1235. Instead, he undertook a long missionary journey in the provinces in order to spread the new faith. When at last he returned to the capital at Kyoto, Shinran found that his views could not be reconciled with those of Honen's followers. In order to 
perpetuate his ideas, he founded the Jodo Shin Sect, which has since existed side by side with the Jodo Sect. Shinran is remembered not only as a powerful personality, but as an innovator who introduced new views of great significance. In particular, he wished to break down the barrier between priest and layman. He not only ate meat and other food forbidden to priests, but married openly.

The doctrines of Amidaism became dominant over the mystical abstractions of other sects because they were easily understood by the common people. Today, there are probably over twenty million Amidaists in Japan. Their worship is directed not only to Buddha, but the Bodhisattvas Kwannon and Daiseishi, representing benevolence and wisdom respectively. This many-sided cultus offers the promise of life after death, even as it ministers to joy and sorrow in the present life. By and large, meditation has become secondary to "calling on the name of Buddha." The priests themselves have some special ceremonies and disciplines which are not given to laymen.

Renyo, 1415-1499, the eighth patriarch of Jodo Shin, is sometimes called the "second founder of the sect." Like its first leaders, he was careful to make his teachings understandable for the simplest person. Renyo strengthened the ethical emphasis of the school, insisting that each individual must be true to his duty as a citizen of the state and member of society as well as to his own household. Ethics and religion are inseparable, because obligation is grounded in faith. Renyo taught that assurance of salvation is possible in this life, but enlightenment can be attained only in the "pure land" after death. His statement of the creed summarizes its teachings:

Rejecting all other religious practices and works and all idea that I can help myself, I pray wholeheartedly to Amida for my salvation in the life to come, which is the most important of all things. I believe that the moment $I$ have faith in 


\section{Buddhism}

him my entry into the life of paradise is certain, and I exult in the thought that henceforth invocation of his name is an expression of thankfulness. Moreover, I remember with thankfulness that I have learnt this doctrine by the grace of the founder and of the righteous and wise men who succeeded him. Further, I will observe all my life the commandments as appointed. ${ }^{14}$

The phrase "rejecting all other religious practices and works" has distinguished the adherents of Jodo Shin from most other Buddhists in Japan. They have perennially resisted government attempts at merger with Shinto.

Zen Buddhism came into its own at the end of the twelfth century, the period in which Amidaism also developed, and has made a singularly large contribution to architecture, literature, drama, painting and dancing. Zen teaching had been introduced from China at the time of the Nara sects, but was not widely accepted until the period of Amidaism. It is interesting, perhaps paradoxical, that this school should develop at the same time as the Pure Land sects. Zen apologists argue that their teachings are the closest of any sect to the ideas of the historical Buddha; yet they also emphasize that his ideas are not at all necessary in the realization of its truth. Zen practice seeks to transmit Buddha's mind directly to the believer. Enlightenment comes only by intuition as history and concept are transcended. Silent meditation and abstract contemplation rather than sacred formula or faith in a savior are made primary. Bunce's explanation may help the uninitiated: an immediate aesthetic perception of reality is sought through meditation, which is not possible through usual channels of reasoning but only by "spiritual telepathy."15

Enlightenment is possible because a fundamental unity underlies all experience. Zen teaches that this unity belongs to existence itself rather than to concept or idea. Zen priests generally prefer paradox or contradiction to simple formulae. Enlightenment is possible only as man absorbs the universe 
into himself; through meditation, in particular, his mind becomes a holy vacancy. Zen discipline offers elaborate rules for controlling the mind in order to attain escape from consciousness and become one with reality. It not only disregards the superstitious practices of most other Buddhist sects, but claims to be free of scriptures, mystical formulae and even asceticism. Zen's freedom from the historical Buddha explains why it has been associated with Confucian philosophy throughout much of its history in Japan. It is not primarily militaristic in its emphasis, although Zen meditation has been used as a discipline by the warrior class. At present, Zen sects claim ten million followers. The two most important leaders in Japan were Eisai, 1141-1215, a Tendai priest who studied in China and founded the Rinzai sect, and Dogen, 1200-1253, who established the Soto sect; this latter group emphasizes book learning as a supplement to meditation.

The most indigenous school of Japanese Buddhism was founded by the reformer Nichiren, 1222-1282, whose biography is still widely read in Japan. Like the founders of the Zen and Amida schools, Nichiren first studied Tendai doctrine. However, he came to regard all sectarian differences as perversions of S'akyamuni Buddha's original teachings. Nichiren wished above all else to restore Buddhism to its pure form. He concluded that this was possible from study of the Lotus Sutra, a Mahayana Buddhist scripture which he regarded as more authentic history than present scholarship allows. This document joins alleged history and theology. The first part treats the historical Buddha, while the second half is concerned with the eternal Buddha of original enlightenment.

Nichiren did not intend to found a new sect, but only to return to pure, original Buddhism. In the end, more than any other Buddhist teacher, he gave an important place to a 


\section{Buddhism}

written Book, the Lotus of the Pure Law. Moreover, he denounced all sects, calling down special condemnation on the Pure Land doctrine of a Western paradise. Nichiren's intolerance and reforming zeal soon evoked persecution. When he was driven from his native province, he went to Kamakura, the seat of the Shogunate rule, and denounced the corruption of the government as well as religious practice. $\mathrm{He}$ regarded the separation of the court from the military government as a sign of national disunity, and prophesied that both religion and the state would be destroyed if Japan remained a divided nation.

In spite of these dire pronouncements, Nichiren was a patriotic enthusiast who rallied support against the Mongol invasion. Once sentenced to death but in the end only banished, he finally came to be accepted at court. In the later part of his life, he thought of himself as the reincarnation of Bosatsu Joygo, the disciple of S'akyamuni Buddha mentioned in the Lotus Sutra. Nichiren's combination of religious fervor and political zeal continues to have a wide appeal among the middle and lower classes in Japan, even though his teachings have perennially made for sectarian conflict. Bunce writes:

Nichiren Buddhism is a development from elements present in Tendai doctrines, but, in contrast to Tendai, its doctrines are narrow and exclusive. In Tendai, the Lotus Sutra is only one of the scriptures; in Nichirenism, it is the only scripture. The virulent attacks on other sects by Nichirenites grew out of this conviction. And, within the ranks of Nichiren's followers, many of the sectarian controversies have raged over interpretation of this sutra, some sects claiming the superiority of the "true gate" portion while others maintain that both parts are essentially identical. ${ }^{16}$

Today there are over two million followers of Nichiren sects; this form of Buddhism also has wide influence among the New Religions. 


\section{CHRISTIANITY}

7 HE SLOW growth of Christianity in Japan gives a sig1 nificant clue to the Japanese orientation in religion, particularly as it bears on Western culture. There are over four hundred thousand Christians in the country, approximately half of whom are Roman Catholic and half Protestant. Each of these groups grows at the rate of about twenty thousand per year. ${ }^{1}$ The Russian Orthodox Church is also represented in Japan. Although Christians are less than one-half of one per cent of the population, their influence is perhaps comparable to a religion totaling ten percent. Christianity came to Japan as a well-developed religion, having passed through many centuries of growth and change in Western Europe. Japanese often observe that it adapted itself to Greek and Roman rather than Oriental thought forms in its early centuries.

Christianity was first introduced in Japan in its Roman Catholic form. Francis Xavier and two other Jesuits arrived at Kyushu Island in the southernmost prefecture of the country in 1549. The Japanese believed at first that the Christians represented a heretical sect of Buddhism. The local rulers treated the missionaries well and on occasion even ordered mass conversions. Nobunaga Oda, the first of the three leaders who united Japan, was engaged in a campaign to break the power of the Buddhist monasteries at Kyoto; he also desired contacts for foreign trade. Consequently, he favored Christianity, and by 1582 the Jesuits reported 150,000 Roman Catholic converts. Representatives of other orders were also active in Japan, carrying on medical and charitable work. The 


\section{Christianity}

Japanese government's policy of tolerance continued until 1587 when Odo's successor, Toyotomi, issued a ban against Christianity.

A variety of suspicions led to the persecution of Christians before the turn of the century. Toyotomi was alarmed by the dissention between the Jesuits and the Franciscans and feared that their disagreements might lead to strife in the body politic. Moreover, Protestant traders from Holland and England claimed that Roman Catholic missionary activities were a prelude to foreign aggression and conquest. The persecution under Toyotomi led to the death of six Spanish Franciscans, three Jesuits and seventeen Japanese converts in Nagasaki. Ieyasu Tokugawa, following Toyotomi, at first rescinded the ban against Christianity, as he desired trade with the West. However, by 1614 he adopted an even more severe policy and ordered the imprisonment, torture, and death of the missionaries and their converts. Christians are variously estimated to have numbered 300,000 to 750,000 at this time. Thousands were martyred as the religion was put down. The climax of the persecution came in the revolt of several thousand Christians on the Island of Amakusa and the Shimabara Peninsula near Nagasaki in October 1637. They were finally destroyed in 1638 in a massacre of over 30,000 persons, including women and children. The Japanese government subsequently closed the country to the Western world, and allowed trade at only one place, the Island of Deshima in Nagasaki Bay, and with only one country, Holland.

Both Roman Catholics and Protestants have carried on vigorous missionary programs since the opening of Japan to the West by Commodore Perry in 1853. A party of priests arrived in the country as early as 1858 and was given permission to serve the foreign communities in Yokohama and Naga- 
saki. A member of this group named Petitjean, who later became a bishop, visited the area of Southern Japan where the Christians had been martyred two hundred years before. He was gratified to find that Christian faith had not been completely eradicated by over two hundred years of government persecution; however, his interest resulted in renewal of strict measures against the Christians. On April 12, 1865, a descendant of the early Christians recognized the cross and statue of the Virgin, and acknowledged his faith to Petitjean. Several thousand persons who had still maintained Christian faith secretly, asked to break their forced relation with the Buddhist temple. Government action was swift and severe. Some of the Christians were condemned to death, although the sentences were never carried out, because of fear of the Western powers. All Japanese Christians were exiled and many subjected to terrible tortures. Over three thousand persons were divided into twenty-one different groups for resettlement. When the ban was lifted in 1873 , only a few had the strength and resources to return home.

The first Protestant missionaries arrived at Nagasaki in 1859 and were spied on as well as forbidden to preach among the people. The government itself supported opposition to Christianity by a policy of inducing fear of the new religion. Buddhist and Shinto leaders encouraged popular prejudice against the new religion. The first Protestant Christians came from the low-ranking samurai who had lost their positions in the Meiji Restoration. Ohata and Ikado comment: "Christianity needed two things to prosper: a valiant spirit to repel government and social pressure, and intellectual ability to understand and propagate difficult doctrines."

The samurai, in particular, wanted to learn about Western culture. Frequently, their intention was not too different from that of the government, namely, to learn Western ways in 
"English instruction with Christianity removed." However, the humane, spiritual concerns of the missionaries soon won out. Ohata and Ikado quote a former retainer of the Shogun as follows:

One day as we were walking together, Shinozaki said with deep emotion that the overthrow of the Tokugawa had been God's will. For me who had come from Aizu (one of the staunchest supporters of the Tokugawa), this was a great surprise. It was the last thing I would have expected from a person who had been so closely affliated with the Tokugawa government. That he should say so casually words I could never forget! But I had real respect for his faith, and felt at once as if $I$ had heard the voice of God. ${ }^{3}$

Government opposition continued until the last two decades of the nineteenth century, when foreign influence led to the acceptance of nominal religious freedom. Yet even before this time, travel abroad by Japanese nationals made clear the positive benefits of tolerance as well as the country's backward condition. The period, 1874-1890, was one of increased receptivity to Christianity, and the Christian Church became established in strength in Japan. New ethical ideals, based largely on Protestant teaching, and the advanced knowledge of Western nations were accepted together.

The first Japanese Protestant churches were founded under the leadership of nationals trained by the missionaries at Yokohama. The Yokohama Band was singularly evangelical, having been taught by persons of great devotion. Strong ties of brotherhood and unity had their background in the persecution of the early period. The members of the Yokohama Band feared sectarianism and had no interest in Western denominationalism.

Two other groups contributed to the growth of Christianity in Japan. The Kumamoto Band was made up of converts who received their education in the provincial cities, mainly under Confucian influence. Its members were less subject to 
missionary direction. Their concern for a strong Japanese Church free of all foreign financial influence reflected Meiji nationalism. The Sapporo Band, made up of graduates of the Government Agricultural School in Hokkaido, were considered the most scholarly and theoretically minded of all the new Christians in Japan. Many of this group refused to identify themselves with the institutional church, often joining independent associations. They were not as much bound to feudalism as their fellow Christians in the South and often had larger breadth of vision. Kanzo Uchimura, the founder of the Non-church group, originally belonged to the Sapporo Band. Danjo Ebina, a Christian pastor, describes the differences between the groups as follows:

Christian leaders in Japan have come from three schools. ... Graduates from Yokohama were particularly concerned with the Christian church. Those from Sapporo proclaimed a kind of individualism. Uchimura Kanzõ, the famous founder of the Non-church group, came and talked to our group about this subject. He said that the Yokohama group were ecclesiastical, the Sapporo group spiritual, and the Kumamoto group national, that is, preaching a nationalistic Christianity. At that time, I said, "Friend Uchimura, you take only the good elements for your side. ... I am referring to the fact that you call your group 'spiritual.' This is common to all three groups. You folks are really individualistic." 4

Christianity in the last decade of the nineteenth century felt the influence of rising nationalism. Indeed, many converts deserted their new faith as a host of problems bore in on the churches: Enthusiasm for the Occident was replaced by conservatism and a strong national consciousness. Most Japanese believed that the Western nations had been unChristian in refusing to agree to revision of earlier treaties on the basis of equality. The government so encouraged nationalism that it nearly lost control of the rising patriotic sentiment.

The rapid expansion of Christianity which characterized the late eighteen-eighties ceased when the government policy 
which supported it suddenly changed. . . . The most humiliating infringements were the extraterritorial rights European residents in Japan had ... government domestic policy was to unify the people and to strengthen the nation so that it could deal with the Powers as equals. In the late eighties, the authorities used the desire for treaty revision to increase nationalistic sentiment and to win popular approval for their policy of national independence based on strength. ${ }^{5}$

The new paternalistic Constitution issued at the beginning of the last decade of the century repudiated the natural rights of man: "In Japan the Emperor bestows the franchise on the nobility and commoners. It is not at all their rights as individuals." None the less, the Constitution granted freedom of speech if the persons exercising it "did not disturb the peace or neglect their duties as subjects." Christians in Japan accepted this Constitution optimistically, even gathering together for a service of thanksgiving during a blizzard in Tokyo. Yet the essentially nationalistic, undemocratic mood of the time soon became clear as Christian internationalism was subjected to strong adverse pressures. The Christian situation was made even more confused as new currents of Western thought bore in upon it. Utilitarianism and evolution were championed by Western intellectuals; higher criticism and "fundamentalism" vied with each other in open debate.

By the turn of the century, the spirit of the times had changed. The revision of the treaties with the West encouraged good will and a new period of stability and growth began for Christianity in Japan. A Three Religions' Conference, in 1912, composed of representatives of Shinto, the Buddhist sects and the Christian denominations was initiated in the face of growing fears that industrialism would lead to materialism. Christian participation represented unofficial recognition of the new religion. ${ }^{\circ}$

Roman Catholic work also expanded greatly in this period. Although it began first among the lower classes and farmers, 
it later developed among the higher social classes more than Protestantism. Christianity suffered some difficulty in the period of the first world war, as the war itself was interpreted as a breakdown of Christianity in the West. Wilson's Fourteen Points and the aid extended to Japan following the earthquake of 1923 changed this feeling somewhat. However, the United States Oriental Exclusion Act of 1924 tended to nullify these gains.

Christian social work was outstanding in Japan before the war, and has often been linked with Western scientific knowledge. The missionaries were leaders in the teaching of new medical science as well as in protests against social evils. The contribution of Christian institutions has also been outstanding. No doubt, the mission schools have been popular in part because they have been Western, largely American. Yet these schools have continually been handicapped by the preferential treatment given by the Japanese government to graduates of its own state schools. Moreover, the government placed severe restrictions on the teaching of religion in Japan, generally limiting it to extracurricular activities. The proportionately large numbers of persons of influence in Japan who are from Christian schools attests to the large success of Christian institutions in spite of difficulties.

The decade before the second world war was marked by a variety of efforts to unify the Christian bodies in a single Church. Pressure for unification came from both the churches and the government. The official recognition extended to the Christian Church for the first time in April 1940 was part of a long tradition of government regulation. State sanction was given only to groups which had at least fifty established meeting places and five thousand members. Protestant leaders undertook the work of unification in an atmosphere which was assuredly not one of freedom. No simple appraisal of their motives can be adequate, in view of the pressures 
which bore in upon them. The different Christian denominations fully separated themselves from the Western churches, as the government urged them to support the war effort which had already begun in China. However, authentic interest in ecumenicity and unity had been growing for a quarter of a century. The Japanese in general have never been as denominationally minded as Western Christians.

A mass meeting of the major denominations in October, 1940, gave approval to plans for a United Protestant Church. The denominations were divided into eleven blocks, which in November 1941 entered into a united organization, known as the United Church of Christ in Japan. This Church, popularly known as the Kyodan, has continued in the postwar era. Some Episcopal parishes and a few smaller denominations such as the Seventh Day Adventists did not join the organization during the war; they were classified as religious associations and put under the supervision of the local police rather than the Ministry of Education. Suspicion of Christians was not abated by Church unity, but continued to grow during the war. Sunday was abolished as a holiday and pastors were mobilized for work in munitions factories. Most congregations accepted the practice of bowing toward the Imperial palace and praying for soldiers who had died as well as for those at the front.

Religious freedom was extended to all religions in the postwar era. Christianity made notable gains, in part because it was identified with the West. Most Japanese believe that Christianity received the support of American occupation authorities, in spite of the fact that American officials claimed to be neutral. No doubt, it did receive some deference as the major religion of the conquering nation, but this is generally exaggerated in the popular mind. The occupation weakened Christianity's effectiveness in a number of important areas; in particular, American paternalism discouraged in- 
digeneous social criticism. Christianity in Japan still suffers from identification with foreign interests. It could only develop real strength in the future under leadership which is unmistakably Japanese.

Christian ideas have had a wider influence than any single denomination. There has been a deep and authentic desire for knowledge apart from the churches in the post-war era. The large popular interest in Christian ideas is apparent from the activities of the Japanese Bible Society whose seventy colporteurs annually distribute hundreds of thousands of Bibles and Bible portions. In spite of all limitations, there is a greater openness to Western religious ideas than in the Meiji era. However, Christianity does not have a strong following in the rural areas or among the urban masses. In fact, it does not have a base among the lower class groups comparable to that in other parts of Asia. In Japan, it has generally appealed to persons of good education in the upper middle class groups. Christians have used educational institutions, particularly colleges and universities, as a means of spreading their message.

The Japanese Protestant Church remains somewhat ingrown and self-contained, in spite of the new and sympathetic hearing which Christianity receives. ${ }^{7}$ A perennial diffculty of Christian work is that it represents a mature, high religion, which demands the end of superstition and naïveté. Moreover, it makes strong ethical demands on both the individual and society. Christian leadership has made extensive efforts to extend the scope of church concerns in evangelism and social witness in the post-war era. However, it has not yet recovered fully from the effects of militarism in the war era. Government pressures were effective against the life of the church in many different ways. Christianity's social appeal was probably larger a generation ago, when it caught the 
imagination of youth somewhat as Marxism did in the immediate post-war era. An outstanding contribution to postwar Japanese church life was made in the visit of Professor John Bennett of Union Seminary in 1950. His realistic Christian social ethic has had a lasting influence on the thought of Japanese Protestant leaders.

In the last few years, growth has been less spectacular, but probably more reliable. Leadership for change has often been modeled on the West, even when it has not come under foreign direction. The Kyodan or United Church of Christ in Japan remains the largest single Protestant body. Its organization is presbyterian, although with large local control and concessions to congregational polity. The General Assembly is the highest authority in the Church.

Ten major Protestant mission boards co-operate with the Kyodan through the Interboard Committee for Christian Work in Japan. Denominational pressures from abroad, however, have led to a revival of sectarianism, and Anglican, Baptist, and Lutheran bodies have separated from the Kyodan. However, a large need for co-operation remains in the non-Christian environment, and the major denominations carry on many common activities. Christian sectarianism does not have a history in Japan comparable to that in the West. The leaders of the Kyodan have a strong sense of national Church and are confident that Western denominational loyalties cannot retain any strong hold in the Japanese community. American Christendom must assume responsibility for much of the post-war division, since missionary funds from abroad still determine church programs in large measure.

East-West relations continue to be beset by serious problems. For example, the Japanese were largely dependent on the West for the financial support of their central church 
headquarters following the war. The high rate of exchange has favored American power. American control has been much larger in these offices than throughout the church in general. In turn, this has made possible a disproportionate influence in church policy by the Americans. None the less, American support has done much to revive the Japanese church and infuse new ideas since the war. A genuinely Christian spirit often tempers resentment against foreign influence.

Steadiness and a sense of balance have not yet been fully recovered in Japanese Christendom. It is unfortunate that the Japanese religious press shows some signs of a return to the nationalist position. On the other hand, Japanese church leaders have not always been as firm as they might, in speaking out for Japanese national interests. For example, a report was published in the press, stating that motion picture profits which were required by law to remain in Japan, were being given to Christian churches. No prompt denial was forthcoming from Christian leaders. Veteran missionaries agree that Japanese denominational officers were churchmen of the highest intellectual qualification and dedication before the war. However, Japanese churchmen suffered a loss of spiritual and moral effectiveness from long co-operation with ruthless militarists in the pre-war and war periods.

The Japanese interest in Christian theology has its own peculiar characteristics. Many Protestant ministers are very well informed about the details of German theology and can discourse at length on the ideas of Karl Barth, Emil Brunner, Paul Tillich, and Reinhold Niebuhr. Theology at times becomes a substitute for life and work, indeed even an escape from reality. It is interesting to observe how a Japanese congregation will often listen patiently to a heavily theological sermon, understanding it only in part, but accepting it with 
an enthusiasm not characteristic of American Protestantism!

Missionary activity itself presents a wide variety of interests and problems. Language is a real barrier to missionary work in Japan, as most foreigners are not genuinely bilingual. International Christian University in Tokyo is an important part of the missionary program. Founded since the war, it has been required to establish an undergraduate college before beginning a graduate school; the latter was a major if not the primary concern of its program. The idea of a bilingual university, English and Japanese, is excellent in principle, but presents real difficulties. Students are in danger of suffering a loss of nationality. The paternalistic character of Japanese education, particularly in job placement, makes it impossible for a new university to develop rapidly.

Virtually every kind of American group, regular and irregular, has appeared in Japan since the war. ${ }^{8}$ Their efforts range from competent, sociologically informed attempts to understand the culture to obscurantist, belligerent efforts at conversion. The missionaries themselves are divided between a group which co-operates with the Kyodan, the Fellowship of Christian Missionaries, and a near-fundamentalist organization, the Evangelical Missions Association of Japan. Urban centers are the easiest places for missionary work, particularly among educated groups. Considering the efforts expended since the war, results have not been large. There are no signs of a mass movement toward Christianity in the immediate future.

The Japanese churches continue to have large inadequacies in their program. They are just beginning to explore the possible use of radio and television as well as audio-visual teaching aids. Protestants are not making full use of the opportunities available in the non-Christian universities. More trained staff and funds are needed in this area. The psychol- 
ogy of pastoral care has failed to keep pace with developments abroad. Many of these inadequacies arise from the limits of the Japanese situation. Salaries of pastors are very low, and average probably thirty dollars a month or less. The resources for ministerial training are not large, and many seminary students cannot even afford an adequate diet. Study abroad sometimes fits the candidate more appropriately for teaching than for the pastoral ministry. Some leaders feel that it is inadvisable for a candidate to study outside Japan unless he intends to go into teaching. Protestant education perennially faces great difficulties, even though there are some excellent Christian schools in Japan. For example, Doshisha University at Kyoto retains considerable Christian influence. Yet, its leadership has felt compelled to place emphasis on large enrollments, which are judged necessary in order to meet expenses in the post-war era. These sometimes become more important than religious interests.

Two significant movements, at opposite poles both socially and intellectually, reflect the demand for indigenous leadership. The Church of the Spirit of Jesus, Iesu No Mitama Kyokai, is a somewhat nationalistic and anti-Western, lower class organization. Its founder, Bishop Jun Murai, a graduate of the Methodist Seminary at Aoyama Gakuin, is still living. Sociologically, Iesu No Mitama Kyokai represents a Japanese movement akin to the New Religions. It emphasizes faith healing and apparently is not fully orthodox in Christology.

The Non-church group was founded by Kanzo Uchimura, a distinguished and revered leader from the Sapporo Band. It claims to be free of churchly ties and has no sacraments. The Non-church movement accepts no institutional program but relies on personal contacts for its leadership and program. Uchimura himself attracted people from a wide variety of strata in society. Following his death, the Non-church 
group has continued as a small minority movement with its greatest influence among intellectuals. The President of the University of Tokyo is one of its present leaders and each Sunday morning conducts his own Bible study meeting. Adherents of the movement are reasonably co-operative in their relations with other Christians. Sigurd Aske, writing in the 1956 Japan Christian Yearbook, refrains from evaluation on the grounds that opinion is too widely divided about the group. ${ }^{\circ}$ Church leaders have reacted defensively and with some justification against its defenders. For example, the Swiss theologian, Emil Brunner, was a very enthusiastic supporter of Non-church activities when he visited Japan. He stated frankly, that he would affiliate himself with this group if he were a Japanese Christian.

Uchimura's own life story illustrates the problems which have perennially confronted Japanese Christians. ${ }^{10}$ It was still a capital offense to be a Christian at the time of his birth in 1861. Uchimura was of samurai warrior background and had a strong sense of loyalty and obedience to superiors. This allegiance was given to God and nation following his conversion to Christianity. Uchimura wrote: "I love two J's and no third; one is Jesus and the other is Japan. I do not know which I love more, Jesus or Japan." "For Jesus' sake, I cannot own any other God than His Father as my God and Father; and for Japan's sake, I cannot accept any faith which comes in the name of foreigners."

Uchimura's first introduction to Christianity did come in part from foreigners, however. This contact had its background in his study of English in a school near Tokyo from 1872 to 1877. Answering the appeal of government officials, he enrolled at the Sapporo Agricultural School in Hokkaido, the Northernmost of Japan's main islands. This school was experiencing an evangelical awakening of the revival type 
when Uchimura arrived, and he first resisted the pressures for conversion which bore down upon him. As a Japanese, he felt strong ties of loyalty to Shinto and Buddhism. Moreover, a deep devotion to duty and patriotic loyalty remained when he accepted Christ. He joined his fellow students in insisting on an independent Japanese church, and supported them in their disputes with the missionaries about money. Uchimura was disillusioned about the institutional church even before he went to America.

Uchimura left Japan in 1884 and returned in 1888. He not only wished to forget an unhappy marriage in which his wife had been unfaithful, but also had high hopes in anticipation of seeing a Christian country. He was disappointed almost at once, in part because of his naïveté. However, there were also lasting influences from his trip to the United States. In Philadelphia, he learned much from the Quakers and Unitarians with whom he worked in a new school for the feebleminded. At Amherst College, he was only a fairly good student. He failed his first course in philosophy, but managed to get most of his work done. President Seeyle of Amherst contributed to his development by directing him away from brooding introspection. Uchimura also studied at Hartford Seminary in the last few months before he returned to Japan. In part because of this diverse environment, his thought combined samurai and Puritan influences. Study of the Old Testament reinforced his stern sense of duty as well as his conviction that the Japanese must work out their own spiritual destiny, even as Christians. Uchimura's ideas and motivation are well summarized in the words which he ordered inscribed on his tombstone: "I for Japan; Japan for the world. The world for Christ, and all for God."

The Non-church movement is widely discussed in Japan today. Its three principles are a Cross-centered faith, Bible 
study, and advocacy of Japanese Christianity. Uchimura himself edited a magazine on Bible study which he ordered discontinued after his death, so that it would not become a center of devotion. Present members of the group emphasize that they accept Biblical criticism, even though their Bible study is in the main practical and devotional. In advocating Japanese Christianity, they wish to go behind the traâitions of Christianity in European culture and develop its truth indigenously. They urge that Christian faith must come without foreign intermediaries. Uchimura refused to worship the Imperial Rescript on Education in 1891, and also opposed the Russo-Japanese War. Although championing Japanese Christianity, the group has also criticized nationalism.

Roman Catholic strategy in Japan is extremely well planned and generally effective. Scores of excellent European scholars, Italian, French, Spanish and German, have been brought to Roman Catholic universities. Protestant scholarship is not as specialized or as much given to research. Roman Catholics also have done excellent social service work, an activity now too often lagging among Protestants. The Roman Catholic Church has emphasized culture as well. For example, the new Cathedral in Hiroshima is furnished with a pipe organ, an instrument which is very rare in Japan. Roman Catholic growth, although not spectacular, has been steady with firm bases.

Only some parishes of the Anglican Church participated in the Kyodan during the war period; the United Church has made them conscious of their own peculiar heritage, and they have now withdrawn completely. Japanese Anglicans claim a middle position between Roman Catholicism and Protestantism. However, they admit that they have practically no contact with Roman Catholicism outside of the Japanese Christian Federation, in which almost all groups partic- 
ipate. Probably in part in reaction to Kyodan low-church practice, they have taken on high-church patterns with much emphasis on vestments and special ritual. They are especially conscious of the apostolic succession as well as of the uniqueness of their own Catholicity. In spite of a new self-consciousness, the Anglicans enjoy good rapport with other Christian groups. One of their clergy was recently head of the All Japan Religion Federation, a post which rotates between Shintoist, Buddhist, Christian, and leaders of the New Religions. Although all of their bishops are now Japanese nationals, they have fine international leadership in their college and seminary in Tokyo.

Japanese church leaders value their contacts with ecumenical Christianity. The first conference on the East Asia Christian Church was held at Bangkok in 1949. The World Council of Churches Special Commission for Southeast Asia has given outstanding leadership. Japanese Christians are hampered in their relations with the World Church by their nation's war record; this is particularly the case among people who experienced Japanese occupation. None the less, church leaders know that a thoughtful, long-range approach is indispensable to Christian work in Japan. The Kyodan has recently established a Research Institute on the Mission of the Church. Its five divisions conform to the study departments of the World Council of Churches: 1. Theology of Evangelism, 2. Method of Evangelism, 3. Church and Education, 4. Church and Society, 5. International Relations.

It is doubly clear that Christianity will require a number of generations of life and work before it can make any deep impression on the Japanese masses. Feudalism and the desire to be buried with one's ancestors retard Christian work. A long period of time will be necessary for Christian ideas to penetrate culture. On the other hand, most Japanese Chris- 
tians realize that their religion has not fulfilled its highest possibilities in their country; it has an unequaled opportunity, which it continues to neglect. While Shinto remains relatively naive and Buddhism continues to disregard modern science, Christianity is too Western and inbred. No doubt, the problem is much more complex than missionary zeal allows. Japanese culture has a long legacy of Confucian hostility to religion favoring secularism. Buddhism contributes to the general view that everything is relative, in particular because it allows no real Absolute, God. There is profound lack of interest among intellectuals as well as crass practicalism among the masses. Christianity would demand a nearly eschatological change in the fundamental bases of culture. Yet, Japan is today undergoing a drastic social and cultural revolution, in the main without the positive benefits of high religion.

Christianity's prestige continues to be good but not excellent among educated groups, particularly among the upper middle class. It is probably regarded more highly than religion and religious leaders in general. Practically, the churches need to develop specific rituals for the very human needs of the masses. Christianity is often too theologically abstract and formless, reflecting many of the weaknesses of American low church heritage. However, by and large, Christianity does contribute more to freedom and democracy than the other religions in Japan. Christian leaders believe deeply that the Christian emphasis on time and history and the importance of the individual is indispensable to the future of democracy in Japan. It can hardly be denied that its doctrines do facilitate the transfer of cultural forms from the West; this, too, presents limitations. In the end, a thoroughly Japanese Christianity, patriotic but not nationalistic, is to be desired. 


\section{THE NEW RELIGIONS}

7 HE SO-CALLED New Religions, the Shinko-Shukyo, 1 literally "Newly-Arisen Sects," are the most important post-war religious phenomena in Japan. In 1952, the Honganji denomination of Shinshu Buddhism, popularly known as Nishi-Honganji, published "A Handbook of Newly-Arisen Sects." This denomination itself was a "New Religion" in the thirteenth century, although later it became one of the major sects of Buddhism and enjoyed strong government support. It undertook this study with a much more tolerant attitude than most of the "Older Religions," which have been vigorously resisting the new cults. The handbook defines a newlyarisen sect as "a living contemporary religion or religious movement which has arisen and grown rather recently on Japanese soil and is nourished by popular support." This type of sect is distinguished from the religions which have come from abroad, such as Christianity and Buddhism, and those which have had state support, Buddhism and Shinto. Moreover, the New Religions generally have a founder who claims special revelation.

Three hundred and seventy-one religious bodies are now officially registered in Japan; before government registration was required following the occupation, as many as seven hundred and forty groups carried on religious work in one way or another. ${ }^{1}$ On the most conservative estimate at least one hundred and twenty of the registered sects must be classified as Shinko-Shukyo. ${ }^{2}$ We have noted previously, that the total adherents of the New Religions are variously estimated at from five to ten million persons. By and large, these groups 
have their followings in the cities rather than the rural areas. They have their major strength among the urban population that was displaced by war and post-war developments. The New Religions fill the vacuum which has been left by the failure of the universal religions, Buddhism and Christianity, to capture the Japanese masses. Some estimates claim that as many as seventy percent of these religions have been influenced by Nichiren Buddhism, probably because of its nationalistic as well as its esoteric emphases. However, there is very little interest in the historical Buddha among them. Buddha, Bodhisattvas and the spirits of the dead are as often as not associated together in ancestor worship.

The new cults are unabashedly practical, emphasizing direct profit from faith and the worship of ancestors; rewards of health and success are promised more easily than in the old religions. The new faiths are optimistic, intolerant and simple in doctrine; they combine the world-affirming, eudemonistic spirit of Shinto with Buddhist mysticism and magic at an elementary level. Most of them have no priests of their own, and some are in reaction against formalism and priestcraft. Yet, all have very strong group ties and organization. There is generally control by the founders, with chief leadership in laymen who have proved their effectiveness in teaching the new faith. Missionary activities are not always benevolent. Charges are made frequently that compulsion in the form of threats of death, illness or other harm has been used to make converts. These religions teach that suffering is occasioned by the individual's own mistakes or those of his ancestors. The leaders warn their followers as well as potential converts of the dire consequences which will come upon them if they do not change their ways.

In some respects, these religions are not new at all, but represent the persistence of feudalistic ideas which have not 
been displaced by science or capitalism. However, other factors must be considered. Most of the religions emphasize healing, even though they are sometimes inhumane in their attitude toward outsiders or even their own members who are in trouble. Although they are primarily a post-war phenomenon, they have a long background in Japanese folk religion. Tenrikyo, a precursor of the New Religions, founded in the last century, still has large appeal in rural areas. Cultural preparation for these movements now can be recognized in the period between the two world wars; wartime movements of population spread their nascent ideas throughout the entire country. The New Religions depend on conversion for new followers and are administered by persons of practical business mentality who are realistic about methods as well as human needs.

The period of greatest growth and development has come since the end of the second world war and in particular since the Korean War. Rissho-kosei-kai, claiming hundreds of thousands of households, is of very recent growth as is also Soka Gakkai, an extremely unco-operative group which has recently elected three members to the Upper Chamber of the Diet. $^{3}$ In fact, exclusiveness and intolerance run very high throughout the new faiths. They are counteracted somewhat by the New Religions League with which more than sixty groups are affiliated. Presided over by a Buddhist who professes a measure of neutrality, it attempts to stop abuses, especially threats of illness, when the prospective convert refuses to accept a New Religion. The League also resists government interference and pressure, particularly of the types dominant before the war. Positive benefits as well as united strength have continued to grow as the leaders of the younger and older cults have had contact with each other in its meetings. When there is evidence of compulsion, the 


\section{The New Religions}

executive secretary talks privately but frankly with the leaders of the sect concerned, even though more deference is shown to them in public.

The beliefs and practices of these religions again make clear that Japanese thought has never undergone a moral and spiritual purification comparable to that of the Reformation and Counter Reformation in the West. It is especially disappointing that change has not been marked by a larger growth of spirituality. To be sure, the older bodies have lost some members to the new sects by conversion. However, the traditional religions suffer most of all from sheer impotence; they have left a vacuum in which mundane satisfactions and worldly profit are esteemed highly. The New Religions have some precursors in the later development of Buddhism in Japan, particularly in Nichiren Buddhism. None the less, by and large they are expressions of piety which are very different from the older faiths. They have appeared in a time of great moral and social crisis, when the Japanese family system with its traditional values is being challenged as never before. The New Religions seek to protect their adherents from the practical effects of spiritual and moral harm in a time of uncertainty and difficulty. Little attention is given to philosophy or a well-trained priesthood. More often than not, they do not seek a reasonable way, but turn rather to traditionalism and magic, both of which are rationalized in limited measure in a sort of theology!

Different emphases have appeared in the development of the New Religions. Omoto-kyo, one of their most important predecessors, was in part eschatological. It taught that the present world would disappear and be replaced by a new and more perfect one. During the war, national power was recognized as a major means of stability and happiness. More recently, health, wealth and power as such have been pri- 
mary. Part of the strength of these sects arises from their use of small groups with individual leaders and strong ties of personal fellowship. Housewives meet during the day, men more often at night, and discuss the most personal problems with absolute frankness. Respect for ancestors joins them to the past. Buddhist and Shinto symbols are often used side by side with various shades of meaning.

Although syncretism dominates in most of the sects, Christianity contributes very little. Its impact has not been significant at this level of the population. Neither is there large Marxist influence among the adherents of the New Religions, as the New Religions are themselves an alternative to Communism. Theologically, the religions generally depend in large measure on the word of the founder or leader, whose direct pronouncements take precedent over any systematic interpretation; about ten percent of such founders are women. The New Religions center around strong personalities and the largest unknown factor is how they will develop following the death of their founders. Officially, the activities of the religions are managed by a board of directors or similar body in which the founder has a major voice. Inasmuch as their goals are primarily sectarian and personal, most of the sects disavow politics. Soka Gakkai is an exception only in part; its principal solution to national problems is simply adoption of its faith.

The long policy of government regulation of religion in Japan has been a perennial concern of the New Religions. Many of their leaders suffered persecution and imprisonment during the war. Following the war, government supervision was conducted under the Religious Bodies Ordinance. This ordinance has been superseded by the Religious Bodies Law of 1951, which assigns the responsibility of recognition to the Ministry of Education. A minimum number of adherents and 


\section{The New Religions}

facilities for worship as well as nation-wide organization are required for government acceptance. Although there may be some need for such recognition, there is justifiable fear that it may be made an excuse for denying democratic freedom to all religions. At present, there is serious concern on many sides that the pre-war pattern of regulation may reappear. Recently, legislation against the violation of basic human rights in forced conversions was proposed in the Diet. Control will be more effective if the new religions voluntarily resist such abuses themselves. At least one prefectural committee has been established to regulate religion. In some prefectures, the governor is required to give approval before establishment of a branch of a New Religion.

The New Religions have a very different character from most pre-war cults, in part because they belong to an era of fieedom. It is not surprising that the older religions resent their coming. However, they have some contacts with the leaders of the older faiths in the All Japan Federation of Religion. The Japan Buddhist Association, the Bureau of Shinto Shrines, the Federation of Sectarian Shinto, and the Christian Federation are all members of this larger body. Among the New Religions themselves, some sects are classified as predominantly Shinto; others are primarily Buddhist in background. Some groups combine Shinto and Buddhist ideas, while a few have a Christian background. At least twentyeight cannot be classified in any of these traditions. In belief, the New Religions are monotheistic, polytheistic or pantheistic; pantheists are in the majority.

The New Religions may be understood in part from their precursor, Tenrikyo, which antedates them by nearly one hundred years. Tenrikyo was originally a rural folk religion rather than an urban cult; at present it shows marked tendencies toward universalism. A survey of its history and doc- 
trine is helpful in appraising present trends. At present, young people especially participate in its work with great enthusiasm and dedication. Its patriarch is a direct lineal descendant of the foundress; unlike the leaders of most of the New Religions, he is well educated, having studied at a public university. Although his direction is in part paternalistic, his brilliant organizational ability is responsible for much of the continued success of the religion.

Tenri City, located near Nara, the ancient capital of Japan, is a remarkable monument to the sacrifice and living faith of Tenrikyo believers. Its large building program, which has just begun, already includes a university and one of the best museums in Japan. Tenrikyo teachers are required to take a three-months course at Tenri City. In addition, it is perennially a place of pilgrimage for the faithful. Tenrikyo claims over a million adherents with three hundred thousand teachers. It has one hundred and twenty large "headquarters churches" in addition to Tenri City. Sacred dance and festivals as well as special forms of worship, particularly the use of the hands, give dramatic embodiment to its teachings.

Tenrikyo accepts the omnipotence and omniscience of God, although in a somewhat pantheistic context; it regards the cosmos as the body of God. The foundress, Mrs. Miki Nakayama, now known familiarly as "Miki," believed that there is one God full of parental love for mankind; all men are his children. God wishes that mankind shall escape illness and misfortune and has indeed shown how these can be avoided. Although rejecting the idea of karma, Miki taught that the soul of mankind never perishes but returns again and again to this world. Basically, Tenrikyo is a practical way of worship and life. It holds that man suffers evil because "dust" accumulates on the soul; eight kinds of dust along 
with ways to remove them are enumerated. The doctrine of creation is Shintoist. The exact place of the origin of the universe is marked by a pillar in the ground in the middle of the sanctuary at Tenri City; this spot is also open to the sky above. A characteristically Japanese eclecticism is reflected in the doctrine that all religions have good in them. However, Tenrikyo was persecuted during the war as a potential source of opposition to militarism. State Shintoists objected to its doctrine that the soul of the Emperor is equal with all others.

Tenrikyo's most important sacred book is the Ofudesaki, literally, "written." It was composed between 1869 and 1882, and is made up of seventeen chapters with 1711 poems. The other two holy books are of less importance: the Osashizu, is a collection of divine directions written by the early followers of the faith from their own hearing and the Mikagura$u t a$ is a book of sacred songs with words to be sung in Holy Service. Special celebration employs nine instruments, while regular worship uses only five. The foundress began to receive her revelations at the age of forty-one. From that time until her ninetieth year, she believed that she was a temple of God devoted to the salvation of mankind.

Tenrikyo's claim to be a religion of revelation is embodied in the following: "I am the Creator, the true and real God. I have the Preordination for this Residence. At this time I have appeared in this world in person to save all mankind. I ask you to let me have your Miki as My living Temple."4 Although Miki and her family at first declined his request, the deity was persistent. The deity called himself $T s u k i-H i$, in his revelation, declaring that he was not a spurious god or idol. The foundress stressed God's parenthood. As creator of the universe, he was burning with desire to help all his chil- 
dren. "To me you are all My children; therefore I am burning with desire to help all of you." Miki was to guide mankind to him both by writing and personal example.

The religion teaches that the foundress' mind was replaced by that of God at the moment he took up his habitation within her body. This was necessary because all human beings are lost in the darkness of their own souls and have no dependable guide but their own self-centered imaginations. Indeed, they have no immediate touch with the divine heart and do not even know the divine parent who created them. God, the Parent, feeling pity, appeared in the world and revealed himself universally through the mouth of the foundress who from time to time wrote down his revelations. The following are examples of her words: "In this world everything is subject to Reason. So I shall submit everything to it and express it in poetry." "Markl Though I say I go by Reason, I have no intention of disciplining you by the use of force. Nor shall I smite you with the sword of my tongue, but I will warn you with the "tip of My pen."'"

God in revelation compared man's mind to water: It cannot apprehend the divine will because it is foul and muddy. But if man cleanses it of all self-centered imaginations, it will become lucid like water, reflecting every truth. The deity also compared the egoism of human thoughts to the rapid accumulation of dust; each person must continually sweep the dust from his mind. The theology of the sect teaches that God gives men warnings in disease and disaster, encouraging them to free their minds of dust; this "pre-Job" orientation parallels the New Religions. The eight kinds of dust have names which help the individual to reflect on his own person: miserliness, covetousness, hatred, self-love, enmity, anger, avarice and arrogance. Tenrikyo teaches that most men's souls are so covered with dust that they must give up their 
bodies before their natural term of existence has transpired. This weakness even passes from one generation to another: many individuals lack a naturally perfect body because the dust which has accumulated in past lifetimes does not "generate" at once. The foundress enjoined altruism and the practice of harmony as the best "fertilizer" for the future.

The foundress also taught that saving grace of all kinds is available from performance of the tsutome, a ceremony reenacting the act of creation. Ten performers move in unison, singing sacred songs, accompanied by the music of nine instruments. Each performer re-enacts the divine functions in creating human beings. The tsutome saves from disease, calamity and suffering as the joy of creation is relied on eagerly. Indeed, the foundress taught that all mankind should come together in such sacred worship. Tenrikyo mythology includes a long description of creation in which human beings are said to be reborn eight thousand and eight times, passing through all stages of existence. Three periods of time are distinguished: During the first of nine hundred million and ninety thousand years, human beings led their lives in muddy waters. In a second period of six thousand years, they received training in mental power. A third period of three thousand nine hundred and ninety-nine years was one of instruction in reading and writing.

Tenrikyo, like the New Religions, has its basis in part in social revolution. Miki's husband was a cotton dealer nicknamed "wealthy Zambei." Following his death in 1855, financial difficulties set in for the family. Although Miki was not completely impoverished, she none the less shared the feelings engendered by the economic distress of the peasants. In 1867, the ee ja naika dances, in part an expression of economic unrest, were spreading through the whole country. Miki wrote the Ofudesaki, the document which has since be- 
come the main source of Tenrikyo doctrine, during the period of these dances. Ogouchi and Takagi quote a letter describing the general spirit of the times as follows:

In the last two or three days, many lucky charms have fallen from the sky in Yokohama and the people in other places are excited. Everybody is wondering whether similar charms might not fall here also. If this should start here (in Yokohama) and all Edo (Tokyo) be carried away, public unrest would cease; if dances should start in addition, it would be even more fun.?

Miki wished to help her followers achieve a state of religious exaltation which would be "heaven on earth." Like the ee ja naika dances, this state of blessedness was to bring release from suffering and cruelty. Miki emphasized social equality and taught that rulers have no special status before the gods; indeed, she believed that the upper classes of Japan had become puppets of foreign governments. The gods of Japan would soon help the people regain their independence. Until this time, Tenrikyo doctrine should be preached and a state of exaltation induced by dancing to music of various Japanese primitive instruments. Such exaltation would at once bestow practical benefits on all those who experienced it. For example, it would make possible regulation of the time of birth and give strength to the mother, enabling her to go to work immediately after giving birth. It would provide protection against smallpox and other diseases and give secret means for preparing fertilizers and incantations for rain.

The Tenrikyo rites, like the ee ja naika dances, were not only a way to material benefits, but an outlet against grievances that could not be solved by political means. In this respect, they parallel a wide diversity of practices in the New Religions. As Oguchi and Takagi comment: "Those [common people] who had sought practical solutions in the riotous 


\section{The New Religions}

dances at the end of Tokugawa lost themselves in the Tenrikyo dances which provided religious inspiration in addition to the promise of practical relief. Tenrikyo's importance in Meiji religious society was that it tried to answer the basic problems of the masses." ${ }^{\text {"8 }}$ Part of Tenrikyo's Scriptures are deliberately written in common language which the masses can understand; others are more abstract. A few secret books of doctrine are available only to convinced believers and have not been made public on Miki's own command.

Tenrikyo may be compared with one of the most rapidly growing of the New Religions, PL-kyodan. The founder of this latter religion, Tokuharu Miki, died in prison nearly twenty years ago, and part of its success may arise from his opposition to militarism. Strictly speaking, PL-kyodan cannot be classified as either Shinto or Buddhist, but has a special character of its own. Tokuharu Miki had a serious case of asthma while he was still chief priest of a Buddhist temple. Suffering greatly, he heard about a healer who had the unique ability of taking the sickness of another person into his own body. Tokuharu Miki not only consulted him and was healed, but subsequently acquired the power of taking diseases from others himself. His son, Tokuchika Miki, succeeded him following the war, and the religion now claims hundreds of thousands of followers. Headquarters is at Osaka with many branch offices. Doctrine depends in the main on the teaching of the leader, which although sometimes couched in esoteric terms, is primarily common sense. The religion is world affirming but not highly speculative.

The English translation of True Liberty is intended as an introduction to $P L$ for non-Japanese readers. Its unnamed author explains the aim of the religion as follows:

The PL order seeks to elucidate the Way how to contribute to the eternal peace and welfare of mankind by promot- 


\section{The Rice Institute Pamphlet}

ing the realization that men are children of God and by making people attain a state of mind whereby both oneself and others become blessed and happy through freely and powerfully expressing one's individuality in the interest of fellowmen and society under the motto of "Life is Art."

The creed does not seem fully consistent to an outsider.

1. Life is Art.

2. The whole life of the individual is a continuous succession of Self-Expressions.

3. The individual is a manifestation of God.

4. We suffer if we do not manifest our self.

5 . We lose self if we are swayed by our feelings.

6. Our true self is revealed when our ego is effaced.

7. All things exist in mutual relation to one another.

8. Live radiantly as the Sun.

9. All men are equal.

10. Bring mutual happiness through our expression.

11. Depend on God at all times.

12. There is always a way peculiar to every name.

13. There is one way for men, and there is another for women.

14. All things exist for World Peace.

15. Our whole environment is the mirror of our mind.

16. All things make progress and development.

17. Grasp the heart of everything.

18. At every moment man stands at the crossroads of good and evil.

19. Practise at once whatever your first inspiration dictates.

20. Attain the perfect harmonious state of mind and matter.

21. Live in Perfect Liberty. ${ }^{10}$

The author of True Liberty begins by considering the wide variety of human moods: gloomy, militant, joyous, and pensive. Then he writes:

There have been a countless number of sages and wise men who have thought and spoken of good things. And yet human life has remained, as it has been, unsolved. It looks as though we have to be content with human life as it is. But, is it really so hopeless that we can do nothing about it?

No, and again nol Decidedly no! The PL order has solved the problem splendidly. It has at last discovered the significance and purpose of life and what it should be, the things 


\section{The New Religions}

which had ever been sought after by mankind since the beginning of history. Regardless of the kind of problems in human life, it has become possible to give a clear-cut answer according to the individual character, circumstances, and environment of any person concerned. This is a great discovery in the history of human culture. With the appearance of the PL order, it has become possible for the whole of mankind to attain eternal peace and welfare. ${ }^{11}$

In his exposition of PL doctrine, the author explains that the desire for self-expression with its attendant joy, is a normal human instinct. Indeed, life is made pleasant, interesting and even joyful by this urge; its realization embraces a wide variety of activities: a gruesome war, enactment of a law, victory or defeat-all seek the good of happiness. Selfexpression reflects the unique individuality of each human person. Every man in his own way must undertake his tasks with sincerity. Authentic self-realization requires that work shall not be done in a routine way, but with interest and conscious zeal. So performed, it will contribute to the conviction that life is art; the latter is defined as "something expressing the individuality of its creator through an object." "Man's life begins and ends in self-expression."12 The greater the difficulty, the greater the joy. PL-kyodan enjoins its adherents to put forth positive effort, exerting themselves with sincerity in every word and deed.

The religion does not overlook the evident fact that life is full of misfortunes which can only be regarded as failures of self-expression. Domestic problems, hostility between husband and wife, misbehavior of children, professional and health problems, are all signs of deterioration in a world which is "intrinsically a paradise." The cause of all such difficulties, according to $P L$, lies in the fact that people have forgotten God and believe that man can live by his own efforts. In reality, life is full of mysteries; man cannot by himself determine fully the origin of the course of nature. 
Life and the world are a manifestation of the great natural power, indeed a spiritual power which is called nature. This "fountainhead of life and activity not only of man but also of everything else, is called God." ${ }^{.13} P L$ expresses a characteristically Japanese sentiment in its doctrine that the human self is a manifestation of God. In fact, God manifests himself in man, and, therefore, God and man are one. Consequently, man cannot lead a perfect artistic life unless his self-expression is made with the knowledge that God is his substance.

God himself embraces everything, good and evil, beauty and ugliness, truth and falsity, and happiness and misfortune. None the less, man's creative role is an important one. All nature is material for man's art. He is always under the control of the divine law, and yet he makes human laws himself. To be sure, human laws always remain imperfect; man must continually try by various movements to transform the negative into the positive. Human culture moves forward endlessly by man's "liberty of choice." This progress is not only individual but social. "The joy of self-expression is, when we look at it from another angle, a joy which can be felt only when there are other people who appreciate, utilize and welcome one's art.".14

PL-kyodan spokesmen urge that even the most difficult task can be pleasant if it is undertaken with spirit. Artistic expressions made without inspiration are valueless. Moreover, selfexpression should not be selfish, but carried out in a bright mood-kindly, politely, spiritedly and with patient attention. "Man's proper manner of conduct in life consists in feeling grateful to everything and in creating art from everything he happens to come across." Such gratitude is evoked most easily if we understand that the ego does not exist primarily apart from its fellows or the deity. Proper expression in the human community requires the grace of God. 


\section{The New Religions}

Observation of life and society makes it clear that man has the liberty to degrade himself in license and base feelings. When he lives egocentrically, he suffers disappointments, failure in business, loss of friends, an unhappy home life and even personal illness. The whole environment is the mirror of man's mind. When he does not live by the law of God, he suffers "gasho," "ego-phenomena," a collective name for calamity and misfortune. "Gasho" is experienced when life is no longer art but has gone downward in decline and decay. The person suffering such dire consequences is no longer able to solve his own problems, but needs the help and advice of religion. PL's Creed of Twenty-one Precepts for Conduct in Life alone will tell him the mental attitudes necessary for the rectification of his situation. Moreover, perverse mental habits may be unknown to the individual. "Gasho" follows when individuals carry on daily life blindly. Hence, the need for "Shosei Kokoroe," Precepts for Conduct in PL.

"Shosei Kokoroe" teaches, by taking advantage of a gasho, evil mental habits which for a long time, perhaps hereditarily, have lain hidden in one's mind, have formed the cause of various gasho, and have obstructed proper self-expressions. True self-expression can be said to make its start from the moment of receiving a shosei kokoroe and following it faithfully.

Selfishness (jiga) becomes eradicated and gasho becomes solved according to the degree to which a person receiving a shosei kokoroe practices it. The most happy thing about it is, in addition, that the person concerned is enabled thereby to make true self-expressions and to lead a pleasant and artistic life as he wishes. ${ }^{15}$

"Gasho" may be inflicted on a family as well as the individual. Children are the mirrors of their parents' minds. Suffering, illness and misfortune come to them when the parents fail to manage the family properly. Furthermore, there are significant sex differences. Article Thirteen of the PL Precepts for Conduct teaches: "There is one way for men, 
and there is another for women." The precept follows the belief that there are natural masculine and feminine expressions appropriate to each sex. In an emergency, if "gasho" appears so suddenly that there is no time to ask for "shosei kokoroe," the individual may request a "tensho," vicarious suffering; "tensho" remains in force until the "shosei kokoroe" is received. PL regards itself as a training institution for cultivating the power and practice of truth; its teachings are effective only for persons who devote their whole lives to them.

Practice goes with teaching, especially for the novice. Candidates for membership undergo an intensive training period of at least a month. They are instructed to ask fearlessly about points which they do not understand; they are to seek explanations from a teacher whenever they cannot practice a given doctrine. Daily worship is also required in order that the candidates may appropriate the religion for their own daily living. New converts are admonished to approach the PL religion calmly, sensibly, and scientifically as it is put into practice. A high level of spirituality is expected: the incantations and sacred lots found in most Japanese religions are not employed in the PL cultus. Daily worship varies in different times and places. Generally, it is held from 4:30 to 6 A.M. The believers pledge themselves before God that they will lead an artistic life in a pleasant mood and in accordance with divine laws during the whole day. Before the appointed hour, they sweep both the inside and outside of the church, beside making other preparations for the teacher's instructions. In the service, all members stand before the altar and sing the PL Hymn, and then sit down and intone (shikiri) to God. Later, any member who wishes may tell the audience how he has led an artistic life in daily practice. Testimonies are followed by the teacher's sermon and a second singing of the PL Hymn. 


\section{The New Religions}

Membership requires an initial fee of three hundred yen, less than a dollar, and entitles the new communicant to a believer's pocket book, a believer's mark, and a half year's subscription to the religion's magazine, The Artistic Life. A "Treasure Creating" bag is given to each family for votive offerings, which, regardless of amount, express gratitude to God for the happiness created by PL faith. These bags are brought to the altar on a day of thanksgiving, the twentyfirst of every month, and the funds received are used to propagate the PL faith.

Omoto-kyo belongs to a middle period between Tenrikyo and the later new sects. It is of special importance as the precursor of many new sects. Like the earlier form of PL, it was dissolved and its leaders imprisoned before the war. Since the war, it has had a variety of names, Aizen-en, OmotoAizen-En, and now simply Oomoto. Leadership has remained in the family of its foundress, Nao Deguchi; the foundress was succeeded by her eldest daughter, Suni Deguchi, who in turn was also followed by her eldest daughter, Naohi Deguchi. The foundress' religious experience came late in life. Born in 1836, she had her first spirit from the gods only in 1892 and obediently wrote what she was told. In 1896, a young man, Kisaburo Ueda, visited her on the direction of deity, and the religion began to grow.

Nao Deguchi taught her followers how to calm the soul in order to cause it to return to God. She believed that there are gods as well as the creator God; however, the latter is the One from whom all others, ancestors, angels and spirits, have come. Nao Deguchi further warned that there would be dire calamity if Japan did not change its way and return to the mind of God. Her foreboding prophecies could be negated only if country and people realized their own proper nature. Oomoto describes evil as love of self rather than of others. 
Respecting the future, it teaches that God has made the world and intends to develop it; the universe will continue to exist and flourish even though human society may be destroyed.

The basic mood and content of the religion are expressed in its four Precepts of Life: First, reconciliation, the heavenly way of worship. This way is twofold, a tangible way of thanksgiving in which offerings are made and prayers recited and an intangible way of worship in which prayer is made to God in spirit and with supplication. The second precept is revelation, manifestation of heavenly truth. This truth is contained in the Scriptures of the sect, although not exhausted by them. Some other revelation appears in history. Indeed, "Oomoto is a miniature epitome of the world. What happens to Oomoto, good or evil, that will happen to the world in magnified form." ${ }^{.18}$ Members believe that persecution of Oomoto by the police was a prototype of the Pacific War. The third precept is one of innateness, human unity or fellowship. Oomoto teaches that all men are united by a bond of fellowship, even as the angels; it is the purpose of religion to help man unfold the love and wisdom of this bond. The fourth precept is one of productiveness, common transactions of life. It prescribes a change from labor for desired payment to the free service of God and fellow man. The four principles of the religion, in particular, give evidence of its Shintoistic character: purification, optimism, progressiveness, and unification. The last is the recognition of the common moral purpose of mankind in God.

Oomoto has taken an interest in religions outside of Japan, particularly in Vietnam and India. It has also expressed special concern about such world problems as the atomic bomb. Oomoto's teachings include acknowledgment of God's creation and ownership: All things are created and owned 
by God and must be returned to him. Man, their caretaker, is to acknowledge God's bounty with gratitude. Its Scriptures say:

The people forget about the hardships of life our forebears experienced at the beginning of the world. They had nothing to be clad in, except the leaves of trees; they lived feeding on grass without even an edged-tool to cut with, and they dwelled in caves. But by the grace of God and thanks to His ministering angels of Heaven and Earth, man's life became more and more easy and comfortable. Remember that without God's protection, there would not have been brought such comfort of life to you! Men are forgetful and ungrateful to God, the Creator of the World. The more civilized they were, the more wayward they grew, and there are at present very few who are now sensitive enough to know the feelings of God. Nearly all are swayed by egotism and have turned the world into a world of beasts, where the weak fall prey to the strong. If men continue in this way, this world will become a world of inhuman monsters and ogres. This is the end of this world of yours and the beginning of a New World of God's. The time is ripe for the Reconstruction throughout the World. ${ }^{17}$

The religion teaches that God's divinity is unbounded and beyond all description. Invisible to human eyes, he cannot even be described in language. Yet, the mind of all living creatures is the soul of the One true God. Moreover, nature is to be thought of as his body and its functions as his energy. Although the universe is only a fragmentary manifestation of divinity, all that exists is the expression of deity. In addition to the physical universe, there is a spiritual world, which is divided into three parts: the celestial or heavenly, the intermediary, and the infernal, hell. Following death, man goes to the realm which corresponds to his habits of will, love and thought. Knowledge of the larger realm of existence, it is alleged, will help the individual to realize his own earthly destiny. Reincarnation is accepted as a possibility for some persons, and there is a strong emphasis on angels: man is enjoined to follow the example of these beings rather 
than to give himself over to the materialistic world view.

Believers meet at least once a month at a time and place set by the local branch. Winter, spring, and autumn festivals are held at Ayabe, the home of the foundress in her later life, and believers are encouraged to make offerings of at least one hundred yen. Branch offices are under the direction of the main headquarters. The group now claims one hundred thousand registered members, forty-three hundred missionaries, and seven hundred branches; there is at least one branch in each prefecture in Japan. The sect also claims three thousand non-Japanese believers in Brazil. Before 1935, much stress was put on healing. Now, primary attention is given to preaching and missionary work, although believers may indeed pray for healing.

A number of New Religions are made up of groups of people who have broken away from Omoto-kyo. These various sects have developed differently in part because of the variety of emphases in Omoto-kyo itself. Taniguchi, the founder of Seicho-no-Ie, was formerly affiliated with Omoto-kyo. The New Religion which he founded emphasizes missionary work by publication and "literary writing." Nakano, founder of Ananai, gave priority to teaching while Okado, the now deceased founder of the World Messianity Church, stressed healing.

Seicho-no-Ie, the House of Growth, claims an intellectual following and spreads its teachings largely by publication. It encourages Christians, Buddhists, and Shintoists to keep their own religion, while yet finding new life through its teachings. Seicho-no-Ie is ethically sensitive in its criticism of modern materialism and assuredly gives its followers a remarkable joy and peace of soul as well as enthusiasm for its cause. Its founder, Masaharu Taniguchi, born in 1893, co-operates with the leaders of the Religious Science movement in America. 
However, his practice reflects the dominant attitude of Japanese piety in such customs as prayers for ancestors. Taniguchi's teachings also include some Hindu elements which in the main have come from the West. For example, God is described as the reality underlying all phenomena as well as first cause. Karma is accepted in limited measure, but may be broken when one realizes his own divine sonship. Taniguchi believes that sin is an illusion; the true self exists in wisdom and love apart from any such limitation.

The founder's autobiography is included in his recent Divine Education and Spiritual Training of Mankind, published in 1956. ${ }^{18}$ Robert H. Bitzer, President of the International New Thought Alliance, contributed a foreword to this volume. Taniguchi's major ideas developed while he was an interpreter for an oil company, following his studies in English literature at Waseda University in Tokyo. Eventually, he suffered the double loss of broken health and theft of his life savings. Even before these disasters, however, he had become interested in the study of psychic phenomena, including visions and contact with souls of the dead. The beginnings of Seicho-no-Ie were occasioned by his own personal problems. Taniguchi describes how he overcame them by the following realization: "Infinite power dwells in me NOW. NOW is infinite life. I am receiving infinite wealth NOW. All went well when I truly understood that infinite power dwelled in my life NOW."19 At first he thought healings a marvel, but then concluded: "If Gautama was right when he said, "THE WORLD IS THE MANIFESTATION OF MIND,' then those who progressed mentally through reading [Taniguchi's magazine] should enjoy better health and livelihood."20

Basically, Seicho-no-Ie is a monistic religion emphasizing 


\section{The Rice Institute Pamphlet}

harmony. Its teachings assert that no rules can be given to the truly religious person; rather, each man must live according to his own divinity. The teachings of other religions are to be respected. According to Taniguchi, Seicho-no-Ie is not necessarily a religion at all. Rather, it is a non-denominational enlightening truth movement carried on through "literary writing." He holds that there was only one religion in the beginning; knowledge of its single truth given in Seicho-no-Ie can serve to inspire and illumine all subsequent religions.

Taniguchi argues that Christians are mistaken in believing that Jesus alone was divine. It is the greatest of sins to center attention on Jesus-the-flesh rather than on the eternal deity. All men can be free of $\sin$ if they only realize their essential deity. Sin is only a wrapping which conceals reality. Spirit must triumph over flesh and the sin idea which binds man. When the outer covering of alleged guilt is removed, it becomes clear that man is really a son of God.

Taniguchi's interpretation of Christian Biblical material, oriented more on theosophy than theism, is taken in part from Troward's Bible Mystery and Bible Meaning which was published in 1913. He interprets rebirth as the sudden dissipation of the idea that the individual is a child of sin and recognition that he is a son of God. Taniguchi emphasizes that repentance does not require a man to despise his own self or fear the last judgment; indeed, fear is symptomatic that repentance has not been experienced. The pious are not to brood over the old self but rather discard it and throw it away.

The Holy Sutra of Seicho-no-Ie includes the following:

One day an angel came to the "Seicho-no-Ie," and sang:God who is the creator of the whole universe

Is beyond the five corporeal senses,

Even beyond the sixth spiritual sense of human beings: Holy, 


\section{The New Religions}

Consummate

Infinite,

Spirit that permeates the universe,

Life that pervades the universe,

Law that regulates the universe throughout:

Truth,

Light,

Wisdom,

Love that is absolute:

These are the very traits of the Grand-Life-God above all relativities;

When God reveals himself,

He appears in Goodness, and in Justice and in Benevolence:

Then Harmony comes of itself;

And each living being finds his proper place and there is no longer any need to fight each other, to conquer each other, nor to suffer from any disease or agony whatever, and none shall remain in need.

God is, indeed, all in all,

God is everything and absolute,

Nothing exists without God:

God is holding all beings in his hand,

Nothing indeed exists that does not come of Him. ${ }^{21}$

Do not take Matter to be Real

Which you perceive through your corporeal Senses:

Matter is not the substance all things are made of:

It is not Life, nor Truth indeed,

Matter has no Intelligence in itself, nor its own Sensations:

Matter is "Nought" after all,

And has no properties of its own.

It is nothing beyond "mind" that gives matter its qualities and properties.

When "mind" thinks of health, man informs himself that he is healthy,

When "mind" dwells upon illness, he informs his heart that he is unhealthy:

It is just in the same way as you see a wrestler upon a cinema screen when you project his image upon it, or you see an invalid there again when you cast his figure upon it;

Yet the film itself is transparent, and has neither shadows nor colors of its own. ${ }^{22}$

Taniguchi claims to be an expert on the problems of women. His chief reference is psychological. Daily practice 


\section{The Rice Institute Pamphlet}

and examination in life as well as personal testimony, study and zeal are enjoined. Taniguchi's position may be further summarized in his own words:

To be saved by religion means restoration of the original freedom of 'life,' and does not mean man's 'deliverance as it is with $\sin$ in an exceedingly pleasant world called World of Paradise" as if scooping up a "mud-smelling-carp" from the mud and putting it into pure water. . . . Christ preached "The truth shall make you free," because Judaism preached, "Humanity has Adam's original sin, and humanity is inborn with sin. ..." However, "Christian Churches" still think that Jesus is the only "son of God," and the ordinary people are all "children of sin," but this is not "Christianity that liberates humanity" which Jesus preached. Jesus never preached man as a "child of sin," but preached all humanity as "Children of God. ..." Buddhism is considered a religion of liberation; from what does it liberate? It delivers humanity from the sinidea, and liberates and makes humanity free. It was Buddha who taught the thought: all is vanity and nothingness, ultimately there is no "permanent thing," all things are transitory; there is nothing fixed, therefore the thing called "sin" is not a fixed thing, all self-tormenting austerities are in vain, they are futile. .. . However, after the death of Gautama and Christ, many of the followers (with the exception of a few disciples) like the proverb "The disciple is inferior to the Master," in complete opposition to the will of the founder of their religion, Gautama and Christ, grasped humanity's sin in the mind. ${ }^{23}$

A more explicit Buddhist influence predominates in other of the New Religions. This may be illustrated from Risshokosei-kai, one of the fastest growing of all the new cults and one which uses the rosary and Buddhist sutras. The sect has two living founders. Mr. Nikkyo Niwano is described as a devout person since early life, long interested in fortunetelling among other aspects of religion! Although he had only an elementary school education, he was very effective as a religious teacher. Originally, Niwano was a leader in Reiyu-kai, another of the new cults; while still one of its teachers, he met the co-foundress, Mrs. Myoko Naganuma, 


\section{The New Religions}

a physically weak person who was greatly helped by Niwano's instruction. Niwano's classes eventually grew very large, and the two founders decided to break away from Reiyu-kai and form their own group.

The foundress, now often in a semi-trance in which she receives inspiration from God, can tell what the ancestors are thinking. Rissho-kosei-kai teaches that parents' souls never die, but rather want to warn their children of the dire consequences that may follow from evil action in the future. Moreover, it enjoins its living followers to plant good seed for future generations, warning them to practice repentance and self-reform. The living must suffer for the misdeeds of those who have gone before them. Emphasis on this latter idea has been so great that some members of the group have broken psychologically under the load of past evil which their ancestors allegedly have left them. Rissho-kosei-kai has bright, crowded sanctuaries. Ancestor worship appears in a context in which Buddha is respected and even worshiped, although ultimately he is regarded as more universal than a personified God. The remarkable growth of the sect is reflected in its Tokyo headquarters which includes a hospital as well as training facilities. The largest building cares for over three thousand persons in small meetings daily.

Another of the New Religions, Gedatsu Hoon Kansha Kai, the Society for Emancipation, Requital of Favor, and Gratitude, illustrates the large persistence of Shintoism in the New Religions. It is of special interest because it accepts this tradition more wholeheartedly and completely than related sects. Gedatsu Hoon Kansha Kai is characteristically Shinto in emphasizing the dependence of man on nature. Its founder, Seiken Okano initially had no intention of becoming a religionist, but only carried on his work in the spirit of prayer. Nature, he believed, is benevolent even in disaster. 


\section{The Rice Institute Pamphlet}

True religion is fulfilled in action which shows the greatest degree of gratitude to nature. Nature's creative force allows for new growth, reconstruction, and new crops, in spite of disaster. Religion is not just gods, scriptures, or ritual. To be sure, there are many gods to whom one must pay respect. Yet, basically, it is an attitude of harmony and gratitude toward nature.

Respect for ancestors is also central in Gedatsu Hoon Kansha Kai. Its present leaders regret that its strongly paternalistic emphasis is less acceptable to the Japanese population outside the homeland. They are not prepared to give up authority in principle. Obedience to parents, the Emperor and ancestors, they insist, is implicit even in the heart of a child. Gedatsu Hoon Kansha Kai's sanctuaries, mainly Shinto in character, are brighter and lighter than those of the old religions. Like a number of the New Religions, it accepts traditional funeral rites, but will conduct the funeral ritual when necessary. It will probably supervise more such rites as time progresses. Moreover, it allows its adherents to continue attendance at Buddhist temples and Shinto shrines. Unlike most of the New Religions, it does not encourage its members to come to the headquarters for worship, but to go out in all places. The themes of its worship are characteristically Shintoist, but its members also practice Zen meditation. Its leaders claim fifteen thousand members who pay the monthly fee of twenty yen; in addition, they estimate that seventy-five thousand persons are related to paying members and also support the religion. There are two hundred and twenty branches, forty of whose heads are women.

The "Code for Youth" is as follows:

Thank Heaven and earth for all the favors bestowed on you, for requital of favor and service are the ways of man.

Follow the ways of man and bestir yourself; 


\section{The New Religions}

the establishment of peace is your duty.

Despite the waves which surge and roll, the will of Heaven is firm and invincible.

$B e$ self-possessed and persevere, be unshakable in all difficulties.

Possession of Truth stirs one's mind; tread on the ground and attend diligently to your vocation.

Strive hard and live in harmony. by cultivating virtue, the grace of nature will without fail be conferred upon you.

Despair not by the gloomy path of life;

there is the bright morning light waiting ahead.

Step forward and look up toward the great sky; there you will find light and hope.

Do not get angry, do not blame others, nor torture yourself; good and evil are both your examples.

Forget all grief and march onward; where there is a will, there is a way.

The "Code for Women" reads:

Let us be thankful for the happiness of being born into this world.

Let us swear to requite the favor of Great Nature.

Let us respect God and the ancestors and let us live in harmony with one another.

Let us live with conviction, observing the ways of man and avoiding errors.

Let us be content with what we are given and abandon grievance and discontent.

Let us try to know ourselves well and retain the virtue of modesty.

Let us lead a life of smiles, gentle, mild and obedient.

Let us share the happiness of others in good faith, discarding all jealousy, envy, and conflict.

Let us utilize things and lead a life in which spirit and matter are in unison.

Let us promote courtesy and enjoy requital of favor and service. 


\section{PHILOSOPHY}

APANESE philosophy has been influenced by Western ideas since the Meiji Restoration. Philosophy, in the Japanese university, signifies primarily European epistemology and metaphysics; Buddhist, Confucian, and Shinto studies are carried on in separate departments. Japanese scholars, initially, gave their attention simply to understanding Western thought. Since the period of the first world war, however, they have attempted to adapt it to Japanese perspectives. Buddhism perennially influences their reinterpretation of Western thought and remains very deep in the Japanese philosophical consciousness.

Japanese universities have more mature, competent scholars than any other schools in the Orient. The major faculties have well-trained, discerning specialists in most branches of Western philosophy. A large body of literature, on the whole untranslated, is evidence that a considerable amount of creative work is accomplished in this field. None the less, outstanding differences between Western and Eastern perspectives, the latter often strongly religious, continue to present real difficulties. Western grammar and thought modes remain formidable barriers for many Japanese scholars. Language and idea often undergo subtle changes of meaning in the Japanese context.

The major traditions of Japanese philosophy have their background in both Mahayana Buddhism and Hegelianism. ${ }^{1}$ Rejection of English empiricism as well as American pragmatism came early, as German idealism was increasingly dominant. Japanese philosophers have been influenced by 
existentialism in the period of its growth and dominance in Europe. However, generally, they hold to their traditional idealistic position and attempt to make a place for existentialism in a rational, inclusive perspective. Marxism and dialectical theology have also attracted attention.

Japanese philosophical studies have been given special encouragement since the founding of Tokyo Imperial University in 1887; a Japanese journal of philosophy was first published in that year. The state decree defining the scope of education in the imperial universities gave priority to respect for ancestors and the duties of the citizen to the Emperor. Hegelian political philosophy was accepted in part because it was believed to contribute to the type of state envisaged. Philosophers had a significant voice in public affairs both before and during the war; some members of the profession wish to recapture this leadership today.

Western philosophy was initially introduced in Japan as empiricism rather than as idealism. Mill's Utilitarianism was translated by Amane Nishi, 1829-1894, the first Japanese to create a modern philosophical terminology in his own language. Nishi studied under C. W. Opzomer at the University of Leyden and also composed the first Japanese manual of logic in the period. The early interest in utilitarianism, positivism, and materialism centered in the so-called Meirokusha group. Its journal, Meiroku Zasshi, featured articles on the thought of Rousseau, Montesquieu, and Haeckel in addition to commentary on the social and political ideas of Mill, Spencer, and Buckle. Spencer was introduced to Japan by Ernest F. Fenellosa, an American who taught in Tokyo from 1878 to 1885, and by a Japanese national, Shoichi Toyama; the latter returned to Japan from the University of Michigan in 1876. Spencer indeed made such an impact on the Japanese mind that the government asked his opinion 
on interracial marriage, a practice which it was widely believed would improve the Japanese racially as well as increase friendly relations with other nations. Spencer, in reply, opposed it for "biological motives."

German idealism succeeded English empiricism and utilitarianism, largely through the influence of three Europeans, all of whom taught in Tokyo, namely, Ernest F. Fenellosa, the American who introduced Spencer, Charles Cooper, an Englishman, and L. Busse, a German. Fenellosa, although partial to English evolutionary philosophy, gave major attention in his course to the history of Western philosophy from Descartes to Hegel. Cooper used an English translation of Schwegler's history of philosophy and also undertook his own introduction to Kant. Busse emphasized the ideas of Lotze. Raphael von Koeber, a Russian, was also among the early Westerners who contributed significantly to the growth of idealism in Japan. Von Koeber held one of the first chairs of philosophy at Tokyo Imperial University. Although especially interested in the ideas of Eduard von Hartmann, von Koeber had very wide historical knowledge. His range of interest included the Greek philosophers, the ideas of Augustine, and scholasticism.

The first Japanese thinkers to become interested in European philosophy often combined Confucian or Buddhist ideas with Western interpretations. For example, Tetsujiro Inoue, who contributed significantly to Japanese philosophical terminology while at Tokyo Imperial University, shows strong Buddhist influence. Tokyo Imperial University was influenced by Kantian ideas in its traditions, while Kyoto Imperial University was more indebted to Hegelianism. Other influences from Germany included Husserl's phenomenology, which became known after 1921, and the existentialism of 
Heidegger. Many of Heidegger's works which have not appeared in English were translated into Japanese.

The Kyoto school, inspired in large measure by the work of Nishida, has the largest influence of any single group of philosophers in Japan. Nishida's attempt to bridge the gap between Eastern and Western thought is acknowledged as monumental on all sides. Although he used Western categories, his basic meanings and inspiration are from oriental mysticism. Nishida's "idealism" is subjected to constant attack by Marxist as well as other philosophers; none the less, it remains the most significant indigenous view. It is unfortunate that his followers became involved in political activities, often in extenuating circumstances, during the war. Tanabe, Nishida's successor, turned to existentialism and mysticism in the immediate post-war period and gave his primary attention to a religious concept of society.

Marxism became increasingly influential in Japan after 1926 and is regarded as a major Western intellectual alternative. No doubt, its popularity is to be explained in part from the Japanese interest in Hegelian dialectic. Dialectic remains a characteristic interest in virtually all modern Japanese philosophy, in spite of a marked reaction against German idealism. Marxism has a negative, destructive role against Hegelianism which somewhat parallels that of pragmatism in America. It also has appeal because it presents a complete world view. Japanese philosophers have shown unusual sensitivity to the social and political milieu in which they work and live. The victory of Communism in both Russia and China has had a significant influence in Japan, as would further victories of this ideology. Japanese Marxists are especially vocal in the philosophical associations. New Russian books are translated almost at once into Japanese. 
The very real social concern of the Marxists, in spite of naïveté, can hardly be denied. Marxism remains a real option philosophically because democracy is not as firmly established in Japan as in the West. Value theory has a direct bearing on political issues and is not limited to theoretical investigation by scholars. Moreover, Communist pressures and influence are of long standing. As early as 1928, Hijame Kawakami became first a Christian socialist and later a Communist; he was dismissed from Tokyo Imperial University. Takashi Ide, the most important conquest of the Communists in the post-war period, was a specialist in Greek philosophy at Tokyo Imperial University. Ide resigned his chair in April 1948 and joined the Communist party. Piovesana reports that Ide's acceptance of Marxism was not due to any deep philosophical conviction, but to the practical belief that only Communism can deal with Japan's pressing social problems. ${ }^{2}$ His recent books follow an orthodox Marxist line, but according to Piovesana, do not show any especially profound grasp of dialectical materialism. ${ }^{\mathrm{s}}$

So-called Communist intellectuals write prolifically, primarily to influence public opinion. For example, Hiroshi Nagata, who died in 1947, had no formal education in philosophy. However, his linguistic ability and training enabled him to translate the works of a number of Communist philosophers, including Deborin. Nagata also composed a history of Japanese philosophy from a Marxist point of view. Shoki Takahashi wrote three volumes on the Philosophy of the People and Ken Yamazaki, a Philosophy for the Millions. In spite of the mediocre scholarship of the Marxists, the Japanese academic atmosphere does not tolerate any outspoken criticism of the left. The critic of Marxism is easily branded a rightist and reactionary.

Marxist ideas appear to have a much larger public among 
philosophers in the Tokyo area than at Kyoto. Existentialism is more central in the concerns of the Kyoto school. Kierkegaard, Heidegger, and Jaspers, as well as Marcel, Barth, Tillich, and Emil Brunner are widely read by the followers of Nishida. Christianity has a significant influence, although it is not as important as Buddhism. Logical positivism and philosophical analysis, primarily from America, also receive some attention. The Kyoto school continues to develop an indigenous creative Japanese reappraisal of both idealism and existentialism, and remains the most vital center of philosophical reflection in the country.

This general appraisal may be made more explicit by reference to particular philosophers representative of different types of thought. Professor Matao Noda is outstanding among the younger members of the Kyoto University philosophy department who are interested in Western ideas. Noda is particularly attracted to Hobbes and Pascal and has given special attention to the latter's voluntarism and interest in science. Although sympathetic to Nishida's point of view, Noda criticizes his dialectical logic, arguing that an exact scientific logic requires revision of the transition points in Nishida's system. ${ }^{4}$

Professor Yasumasa Oshima of Tokyo University of Education completed his doctoral dissertation under Professor Tanabe, Nishida's successor at Kyoto Imperial University. Oshima's study, entitled, "The Historical Decisive Stages of the Ethics of Existence, God-Man and Man-God," reflects a strong Hegelian influence. In this research, he attempted to treat the basic problem of culture in the West. The chapter titles of his dissertation explain in part his interest: "I. Tragedy and the Human Being, the very Moment of the Greek People: The Tragedies of Aeschylus and Sophocles. II. Recollection, Repetition and Expectation: The Living Way of the 
Stoics. III. Sufferings and Trials of Job. Job's Self-Denial of the Old Biblical Men. IV. Nihilism, the Abyss of Human Beings in the Modern World." Oshima has attempted to appraise the basic insights of Christian culture from a philosophical rather than a religious point of view; yet, like most Japanese philosophers, he does not avoid religion entirely. He concludes that the spirit of Japanese culture parallels Hellenism more than Hebraism; Shinto itself, he dismisses as primitive. Oshima agrees with Tanabe's criticism of Buddhism as defective in social ethics, but is also critical of the nihilism of much of contemporary Western European thought.

Professor Takeo Iwasaki of Tokyo Imperial University, who recently visited America, is more Kantian than Oshima. Iwasaki emphasizes that ethical problems have a more urgent practical import in Japan than in other countries where democracy has been accepted for a longer period of time. A faculty member cannot avoid taking a position for or against significant practical political alternatives in his teaching. Consequently, the study of ethics is not simply theoretical, but requires justification of the philosopher's interpretation of the immediate problems of culture. None the less, Iwasaki is sympathetic to analysis philosophy and aware of its dominance in some American faculties. Yet, he regards it as an inadequate perspective for his own positive insights. In particular, he believes that most "positivistic ethics" do not distinguish sufficiently between scientific and normative ethical judgments. Iwasaki's own interpretation grows out of the Kantian tradition of his own University. He has no sympathy with the nihilism which appears in some forms of existentialism, but commends the movement in general for its ethically self-conscious way of living. With respect to the ideas of Kant himself, Iwasaki accepts most of his ethical insights, 
but believes that they are based too much on intuition; some other reference must be found to justify their acceptance. Positively, Iwasaki emphasizes creativity and the importance of the individual in his theory of history and criticizes Nishida on the grounds that he does not give a large enough place to persons as such.

Other schools of thought, beside the dominant Hegelian and Kantian traditions, are also making a significant contribution in Japan today. Most of the interest in American philosophy centers on positivism and analysis philosophy, perhaps in part because they represent a new movement. There is some scattered reading of John Dewey, but very little attention is given to any other types of American thought. Professor Seiji Uyeda of Waseda University in Tokyo, who translated Dewey's Quest for Certainty, is a leading interpreter of English and American empiricism. Professor Uyeda has also worked on Hobbes, Locke, Berkeley, Hume, and Thomas Reid, as well as Mead and Peirce. Fundamentally, he has little interest in the Western tradition of metaphysics apart from the sciences. Uyeda shares some of the anti-metaphysical bias of the logical positivists and analysts. ${ }^{5}$ For example, he observes that Japanese philosophy is divided by two kinds of interest, the scientific empirical on the one hand, and the religious idealistic on the other. $\mathrm{He}$ argues with considerable justification that most Buddhist philosophers have little interest in science. There are surely exceptions to this generalization in such a person as Tanabe of the Kyoto school. Professor Hijame Nakamura, a leading authority on Buddhism at Tokyo Imperial University, is especially interested in symbolic logic.

Whitehead receives little attention, in the main because of his difficult vocabulary. Professor Norimoto Iino of International Christian University has become interested in his 


\section{The Rice Institute Pamphlet}

ideas, however, perhaps in part because Iino studied in America and is familiar with Christian theology. His interpretation of the relation of Whitehead's philosophy to Buddhism has recently been published by Waseda University and has received some attention outside Christian circles. Iino was attracted to Whitehead initially, by his own special interest in cosmology. He argues that the Buddhist idea of immanent causation significantly parallels Whitehead's concept of the occasion. Both regard freedom and causality as part of the immanent activity of the universe. Iino believes that the doctrine of universal immanence is the best insight of Buddhism and ought to be appropriated in Western metaphysics in general. Linked with Whitehead's metaphysics, it may even contribute to a reappraisal of religious differences. Such a synthesis, Iino believes, is a more appropriate vehicle for expressing the insights of Christian theology than the categories of Greek philosophy.

The most important philosophers in modern Japan have been Kitaro Nishida and Hajime Tanabe. Taketi describes Nishida as the first original and universal philosopher in Japan. ${ }^{6}$ Born in 1870 in a small village in the Northern part of the country, Nishida served as professor of philosophy at Kyoto Imperial University from 1910 to 1928 , and died in 1945. His stature is apparent from the fact that he determined the climate of Japanese philosophy for nearly thirty years. Piovesana remarks:

Nishida's special appeal, apart from his brilliant if difficult style, is found precisely in this fusion of profound knowledge of occidental philosophy and a capacity to express the intuitive and non-systematic oriental modes of thought. No other modern Japanese thinker can match him here.

Although Nishida knew the Chinese classics, he took his chief themes from German philosophy. His first major book, 
A Study of the Good, was published in 1911. In this study, Nishida attempted to formulate a philosophy of pure immediate experience. He was influenced from the West by the Marburg school as well as by James and Bergson. In his own culture, he was indebted to several excellent Zen priests as well as to his own Zen exercises and meditation. A strong religious influence appears in his appraisal of both knowledge and reality, as he attempts to express the unsystematic content of oriental thought in the categories of Western philosophy. In short, Nishida undertakes an inner union of Western philosophy and Buddhist speculation. We are given a combination of the ideas of the Western mystics, Hegel, Fichte, and phenomenology, with the "personal self-conscious experience of Nothingness." The latter, Nishida explains, is the Nothingness of Buddhism and not mere ontological nothingness. Nishida's oriental monism is more appropriately described as a panentheism than as pantheism in the Western sense.

Nishida's Buddhist principle of Nothing is antithetical to any essentially positive dialectic or form of the good. $\mathrm{He}$ describes it as "form without form being seen and voice without voice being heard." Nishida explains his position in a variety of statements: The Buddhist concept does not envisage some future linking with Nothing but is the ground of the present; even now, it is dynamic and not merely quietistic or contemplative. Neither does his principle negate something understood or known. It is not antithetical to the being of the self but overcomes it in radical Nihilism. Nishida insists, finally, that the Buddhist principle of Nothing or Nirvana unites culture and history. Interestingly enough, he describes his position as more Christian than Greek, although it is oriented no more on the past than the future.

Noda points out that the way of "nothingness" has a much 
higher value for orientals than the way of "being." Its sense of freedom from egocentricity is preferred to any lasting regard for finite beings. Noda argues that Buddhism and Taoism raise "Nothing" to the status of an ultimate ontological principle itself, conceiving of the Absolute as nonbeing rather than being. Moreover, philosophers of Nishida's school hold that this position is more compatible with modern science and humanism that the Christian idea of God. Nishida, for example, quotes the Zen priest Hoshaku: "All our doings are like brandishing a sword in the air (void)."

Taketi describes Nishida's view as a middle position in Buddhism, between the Vijnapti-matrata-Wade doctrine that outside the soul nothing exists and Sunvata-Vada Buddhism, according to which all phenomena as well as the self are without reality. ${ }^{9}$ Nishida makes self-consciousness the point of unity of the rational and irrational, being and non-being, relation and unity, and continuity and discontinuity; in the end, he gives priority to the will. Nishida's doctrine of pure experience appears as early as his first major book, A Study of the Good. He describes the unity of subject and object, spirit and matter, from the psychology of William James as well as the Buddhist idea of Nothing.

According to Nishida, pure experience is the most fundamental and immediate principle of philosophy. Both knowledge and reality depend on the primitive unity which precedes all subject-object differentiation. Subject and object have a derivative alternative relation; neither can be regarded as true reality and knowledge in itself. The object stands over against the subject in knowledge and inversely, the subject must presume whatever it intends to know. Nishida describes his position as radical empiricism, which is neither merely empiricism nor any form of idealism; in his 


\section{Philosophy}

later works, he sometimes describes it as absolute positivism or realism.

On this view, pure experience is a primitive fact. It cannot be deduced from anything else and yet is necessary to every differentiation in the world. Reality itself is an infinite Frocess of unity; the more advanced its differentiations, the greater its unity. Nishida's view resembles the Hegelian dialectic or the coincidentia oppositorum of Nicholas of Cusa. Pure experience, in essence, is an identity of contradictions which is immediately intuited; its self-development in all its differentiations makes for a greater unity of reality. Moreover, its apprehension in intuition is not aesthetic or mystical but rather ontological in character.

Iwao Koyama identifies three basic themes in Nishida's philosophy. ${ }^{10}$ First, there is a rejection of any exclusive intellectualism. Nishida intends to exclude not only the opposite of voluntarism, but all views which hold that there is a contemplative standpoint outside reality. Both Greek and later German idealism are criticized on the grounds that they make truth such an idea apart from the world. Koyama finds, secondly, a religious motive. $\mathrm{He}$ argues that the idea of an absolute free will which transcends both rational moral and the ethical normative judgments is always in the background of Nishida's thought. Nishida believes that religion cannot be simply man-centered. Thirdly, there is a criticism of anthropocentrism in his view which significantly resembles that of dialectical theology.

Nishida adds a kind of "concrete universal," "a field of nothingness," to his dialectic of pure experience. He was perennially concerned with the problem of identifying a principle of individuation in the universal itself. Nishida claimed to borrow the concept of a field of force from Ein- 


\section{The Rice Institute Pamphlet}

stein. Noda points out that it corresponds in part, in his philosophy, to space in Plato's Timaeus and the Aristotelian concept of matter. Nishida uses it to speak of a positive reality negatively!

Koyama comments at length on Nishida's doctrine of field, explaining that it agrees with his anti-intellectual and antianthropocentric perspectives. Field, according to Nishida, is impersonal or superpersonal; he regards it as the one principle which can save philosophical thought from absolutism. He holds that earlier philosophers attempted such a principle in absolute being; yet he believes that they conceived of it too positively to allow for discontinuity or to relax the dominance of teleology. Nishida refuses emphatically to regard the "ultimate totality" as nothing more than a limiting concept. Rather, as a minimum, he holds that logical synthesis is occupied with "being" in the Platonic sense; however, he seeks to go beyond this to "the unity of being and nonbeing."

Nishida is greatly indebted to German idealism, even when he reacts against it. $\mathrm{He}$ believes that whatever exists in truth is dialectical; identity in itself is the absolute contradiction. Buddhism insists on a dialectic of development and continuity; its paradoxes alone allow for a present field of action. Indeed, Nishida describes it as the absolute negativity of transcendence in an immanence. He explains that Hegel tried to synthesize the Christian doctrine of personality with Greek concepts which in reality are incompatible with it. Spinoza's idea of substance, more than the Christian unity of dynamic action, according to Nishida, is dominant in Hegel's idealism.

Nishida also seeks to include existentialism in his perspective. He insists that individuality must be described phenomonologically; no abstract limits can be imposed upon it. His studies, entitled The Self-Conscious Aspect of the Uni- 
versal, 1929, and The Self-Conscious Foundation of Nothingness, 1931, show a particular indebtedness to Husserl. Nishida is also influenced by Heidegger's analysis of time as well as by dialectical theology, even though he regards the latter as too materialistic. Nishida argues that his position is dialectical like that of Kierkegaard, but allows for continuity and discontinuity. He also is sympathetic to Augustine's totum simul, even though he reinterprets it from his own doctrine of an absolute unity without relation.

Nishida distinguishes between knowledge of the physical world, of the human world and of ideal value, in The System of the Self-Conscious Universal. These distinctions correspond to three fields of nothingness, namely a field of being, a field of relative nothingness and a field of absolute nothingness. The absolute nothingness is described from the dictum of Mahayana Buddhism, "The concrete reality is the void and the void is concrete reality." It is important to note that Nishida identifies the unity of experience with the activity of will. It is intention rather than idea which realizes itself through diversity and contrariety and finally restores the original unity. Yet, in spite of this dynamic voluntarism, Nishida gives intuition primacy over action. He believes that all man's activities are more or less imperfect forms of selfintuition or contemplation. Man's true end is complete vision of himself.

In his Intuition and Reflection in Self-Consciousness, published in 1917, Nishida argues that the unity of self-consciousness is a prototype of all categories. He explains that knowledge starts from the a priori truths of logic and mathematics and progresses "down" to empirical truths which in turn are interpreted as successive products of the one synthetic $a$ priori truth. Although the logical principle of identity is ordinarily taken as a simple analytical truth, Nishida believes 
that it is based on an intuition of self-identity which has the character of an a priori synthesis. He concludes that "A is A" is based on "I am I." Taketi points out that Nishida's position resembles the view once claimed by Fichte, namely, that this original intuition of self develops, producing such concepts as number, time and space among others. ${ }^{11}$ Yet, Nishida insists that the facts of the world, together with their meanings and values, can never be exhausted by $a$ priori logic.

Characteristically, Nishida draws a sharp distinction between religion and other cultural forms, especially morality. Morality, he argues, is concerned with how a man should act, while religion treats his existence itself in life and death. Religion not only gives life its integral character, but makes man aware of the bottomlessness of the historical world itself. In the end, Nishida's ultimate principle of "the identity of absolute contradiction" is not possible or explicable apart from the paradoxes of religion. Nishida believes that Buddhist ideas contain a view of life which hos been presented largely in intuitive forms, such as works of art and the symbols of religion. However, he is sure that they have a logical, ontological scheme of their own. He seeks to show that they make demands not only on the artist and mystic, but on the philosopher as well.

Thus, the ontology of Nishida in its last and definite form presents itself as a dynamic view of reality in the form of a system of paradoxes. A paradox may be defined as a selfcontradictory statement that is not to be put aside as simply false or to be solved away, but is acknowledged as meaningful in itself. ... What ultimately gives unity and meaning to these contradictions is religion ... in general, Nishida's argument for the possibility of dialectical logic ... is simple and straightforward. Usually he refers to the existence of selfknowledge and argues that here lies a self-recurrent, and logically self-contradictory mode of thinking which is based upon an indubitable fact, that there should be some form of 


\section{Philosophy}

thinking where self-contradiction itself can be of vital meaning. ${ }^{12}$

Hajime Tanabe, born in 1885, became the leading spokesman of the school of Kyoto following Nishida. He taught from 1919 to 1945, and since his retirement has spent his time writing at Karuazawa. Tanabe was well trained in mathematics and the exact sciences, and philosophy of science has continued to interest him as he has extended his study to other branches of philosophy. His early Neo-Kantianism reflects the ideas of Cohen; he was later influenced by Husserl and Heidegger.

Tanabe's post-war works give a significant clue to his orientation, although assuredly embodying significant changes of opinion and interest. His Philosophy as Metanoesis, like his Existentialism, Love and Praxis, combines the religious existentialism of Kierkegaard with oriental mysticism. The former is a searching post-war appraisal of the philosophies of Kant, Hegel, Heidegger, Schelling, Eckhart and Pascal. His Dialectics of Christianity, 1948, seeks to reconcile liberal and orthodox Christianity in a dialectical syncretism, combining the Protestant emphases on Christ as Savior and Jesus as Master. Tanabe believes that in principle he has overcome the contradictory essence of religion as it appears in such diverse manifestations as the Koans of Zen Buddhism and the Christian Sermon on the Mount. He cites the resurrection as a typical example of negation which turns into affirmation. The Dialectics of Christianity, like his recent The Need of a Political Philosophy, shows a continuing idealist orientation in spite of the author's encounter with existentialism.

Tanabe is dependent on Nishida's ideas, even though he modifies them in his own interpretation. Taketi holds that Tanabe has a relation to Nishida comparable with that of Natorp to Cohen, Fichte to Kant, or better, Emil Brunner to 
Karl Barth. Tanabe is more deeply influenced by existentialism and Christianity than Nishida; however, the attachment to idealism and Buddhism remains strong in his thought. His deep sense of community led him to emphasize praxis more than his distinguished predecessor. Tanabe's criticism is directed against Nishida at three points: his mixing of metaphysics and mysticism, lack of clarity in the distinction between philosophy and religion, and insufficient grounding of ideas in the folk and national consciousness.

Tanabe insists that a mystical intention dominates in Nishida's reliance on Zen Buddhism. He argues that Nishida did not arrive at his doctrine of Nothingness on exclusively philosophical premises. Rather, it is based on romantic intuitionism and the Zen Buddhist negation of being. Nishida allows for no logic of the species; neither can he give any significant place to the individual comparable with that in Christianity. Tanabe believes that Nishida's attempt to make religion all-inclusive for philosophy and culture ends in nihilism. Nishida's "eternal now" and "absolute nothing" do not allow for continuity and discontinuity.

Tanabe seeks to establish an authentic process dialectic not based on absolute meaning or relation, but on positive reality. Influenced by Heidegger and Jaspers, he insists that time cannot be reduced away in mystic intuition. Nishida's philosophy as timeless, unhistorical and empty, is based too much on a Hegelian, Spinozistic idea of substance. When a religious "Nothing" is made central, particular individuals as well as the state and community are neglected. Tanabe draws on Durkheim's analysis of particular historical communities, insisting that ontology must be in part social. Influenced by both Hebraism and Marxism, he urges that Nishida's quietism must be replaced by a more practical and ethically relevant concern for temporal reality. 


\section{Philosophy}

A number of new ideas have appeared, since the war, in Tanabe's works on the philosophy of science. His Development of Mathematics in Historicism, 1954, was followed by Inquiry into a New Methodology of Theoretical Physics and Dialectic of the Theory of Relativity, both in 1955. In these works, Tanabe attempts to interpret the new theories of physics from a radical historicism while yet maintaining his earlier dialectical orientation. He takes the position that historical time is really dialectical in structure. Although mathematics is based on intuition, it must be interpreted from the radical historicism which expresses the essential characteristic of the actual world. Nagi summarizes Tanabe's view as follows:

Mathematics cannot escape from this historical interpretation of the actions of mathematicians who really construct it, because they are determined by the historical development of mathematics in their own constructive activities. It must be the same with physics. As to mathematics, on the one hand, the intuitionism is too narrow to realize the same truth. Above all, the formalism of Hilbert must have something necessarily to be supplied with radical historism or dialectic of absolute mediation because there must be active conversion between axiom and intuition in mathematics, which is deep-rooted in the historical interpretation of history itself. From this point of view he attempts to manifest the ontological essence of topology, seeing a new method of philosophy of mathematics in it, because topology is like a mathematical expression of historism. And thus he proposes a new idea of the topological set theory basing on historism. ${ }^{13}$

Nishida called his dialectic "the logic of identity of absolute contradiction"; Tanabe, in distinction, predicates his own philosophy on "the principle of absolute dialectic." He charges that Nishida escaped from the true identity of real contradiction by a kind of spatial intuition; in particular, he ignored the contradictory characteristic of time itself. Tanabe, on the other hand, proposes a temporal dialectic in which the past and the future are united dialectically through mutual 
conversion. The present is thus made the real center of action as it is given its proper place in temporality. Tanabe concludes that he has overcome the subjectivism which, he charges, haunts, the thought of his distinguished predecessor.

At present, it is impossible to predict how Japanese philosophy will develop in the next decades. Although a considerable number of competent scholars continue to work in the Kyoto tradition, no single philosopher has taken the place occupied by Nishida and Tanabe. No doubt, Japanese philosophy in the future will continue to reflect the attitudes and interests of the culture at large. The post-war period has brought forth a host of new perspectives which it is not yet possible to appraise adequately. It is too early to say just how Japanese thought will re-orient itself as the decisions of the occupation policy are re-evaluated. On the one hand, Marxist pressures will continue, inspired in part by a desire for friendship with China. On the other hand, the majority of Japanese intellectuals probably will continue to look to Western Europe and America for new ideas.

In the past, there has been a creative interchange between Japanese philosophy and religion. In spite of the many problems which beset Japanese religion today, we must hope that it will continue to make a positive contribution to philosophy. The Oriental perhaps more than the Westerner understands that religion is basic to the life of a people, determining many of its fundamental thought patterns. The history of Japanese philosophy since the Meiji era is evidence that the exchange of ideas between East and West leads not only to reformulation, but also to reappraisal of basic presuppositions. A thinker like Nishida broadens and deepens intellectual inquiry; Buddhist spirituality contributes significant insights at every level of his thought. We believe that the encounter between East and West, which is virtually inevitable 
in the modern world, can be a creative one for religion and philosophy. Both parties to the discussion gain understanding when the problems of knowledge are explored in tolerance but without compromise of fundamental convictions.

\section{NOTES}

\section{Chapter I-Post-War Japan}

1. Seizo Ohe of Nippon University commends Reischauer's comment to this effect. Cf., "The Socio-Political Experiment in Postwar Japan," Ethics, LXVI, 225, and Edwin O. Reischauer, Japan Past and Present (New York: Knopf, 1953), 201.

2. A somewhat limited but important part of the Japanese population is described in Lawrence H. Battistini, The Postwar Student Struggle in Japan (Rutland, Vermont: Tuttle, 1956).

3. Hideo Kishimoto (editor), Japanese Religion in the Meiji Era, translated by John F. Howes (Tokyo: Obunsha, 1956), 23-33. This excellent collection of historical material by a number of authors, adds much to the information available in English on Japanese religion.

4. W. S. Woytinsky, "Japan's Two Worlds," Today”s Japan, No. 6, September, 1956, 1-4.

5. Cf., Tatsuo Morita, "Japan and the Two Worlds," The Annals of the American Academy of Political and Social Science, July, 1954, 23-32. Morita is now President of the University of Hiroshima. $\mathrm{He}$ is a member of the right wing of the Socialist Party, and as a cabinet member advised against the American strategy.

6. Kishimoto, op. cit., 10-13.

7. Antei Hiyane, "Non-Christian Religions in the Contemporary World: Japan," Religion in Life, XXV, 519.

8. Ibid., 520 .

9. Tatsuo Morita, President of the University of Hiroshima, has given an excellent general appraisal in "Educational Reform and its Problems in Post-war Japan," The International Review of Education, I, 338-351.

10. Ohe, op. cit., 253.

11. Ibid., 258.

12. Ibid., 256.

13. Ibid., 260 . 
Chapter II-Shinto

1. Kishimoto, op. cit., 10.

2. Ibid., 14.

3. Ibid., 16-17.

4. Ibid., 24.

5. Ibid., 54 .

6. Ibid., 94-95.

7. D. C. Holtom, The National Faith of Japan (New York: Dutton, 1938), 257.

8. Ibid., 264.

9. Ibid., 266.

10. The Reverend Kanji Sato, Tokyo.

11. Holtom, op. cit., 209.

12. The Reverend Kunimichi Nitta, Tokyo.

13. Holtom, op. cit., 236.

14. Ibid., 237.

\section{Chapter III-Buddhism}

1. Kishimoto, op. cit., 102.

2. Ibid., 131.

3. Ibid., 142 .

4. A journal entitled, The Young East, published by this association, is an excellent record of popular post-war Buddhism in Japan.

5. William K. Bunce, Religions in Japan (Rutland, Vermont: Tuttle, 1955), 52. This book was published under the direction of the occupation religion office and is the best available report, in English, of contemporary Japanese religion.

6. Susumu Yamaguchi, "Development of Mahayana Buddhist Beliefs," in The Path of the Buddha, edited by Kenneth W. Morgan (New York: Ronald, 1956), 153-181.

7. Ibid., 161.

8. Professor Reiho Masunaga of Komazawa University, Tokyo, has written only briefly in English. Cf., The Gist of Buddhist Thought (Kamakura: Enichi-Kai, 1955).

9. Professor Gadjin Nagao has written some short papers in English. Cf., "The Silence of the Buddha and its Madhyamic Interpretation," Studies in Indology and Buddhology, Presented in Honour of Professor S. Yamaguchi (Kyoto: Hozokan, 1955), 137-151.

10. Kitaro Nishida, whose thought is discussed in the last chapter of this pamphlet, represents the Zen position, even though he joins it with other types of interpretation.

11. Sir Charles Eliot's Japanese Buddhism (London: Edward Arnold, 1935) remains the best interpretation of the Japanese Buddhist sects. 
12. Eliot, op. cit., 360.

13. Bunce, op. cit., 74 .

14. lbid., 85 .

15. Ibid., 88-89.

16. Ibid., 95-96.

\section{CHAPTER IV-CHRISTIANITY}

1. Detailed statistics are given in the Japan Christian Yearbook (Tokyo: The Christian Literature Society). The 1955 edition has more detailed analysis than the 1956 issue.

2. Kishimoto, op. cit., 174 .

3. Ibid., 179.

4. Ibid., 201.

5. Ibid., 251.

6. Bunce, op. cit., 153.

7. The 1955, Japan Christian Yearbook, 9-57, gives an account of present problems.

8. The Yearbook, gives a detailed directory.

9. Sigurd Aske, "Trends in the Christian Movement in Japan," 35-36.

10. John F. Howes, the translator of Hideo Kishimoto's Japanese Religion in the Meiji Era, did his master's thesis on Uchimura. Howes is expected to publish his material in time. He wrote a brief article entitled, "Kanzo Uchimura: The Formative Years," Japan Christian Quarterly, XX, 194-208.

Chapter V-Tee New Religrons

1. A detailed directory is available in Japanese.

2. Wilhelm Schiffer, editor of Monumenta Nipponica, has written one of the few articles in English on the New Religions: "New Religions in Postwar Japan," Monumenta Nipponica, XI, 1-14.

3. Soka Gakkai's political activities are summarized by Kiyoaki Murata in The Japan Times, July 21, 1956.

4. Ofudesaki, I, 1. The Short History of Tenrikyo is available from the Nara headquarters of the Tenrikyo Church.

5. Ibid., VIII, 4.

6. Ibid., I, 23.

7. Kishimoto, op. cit., 329-330.

8. Ibid., 334.

9. Perfect Liberty, How to Lead a Happy Life (1951), 1. This book is available from the Tokyo office of PL-kyodan.

10. Ibid., 2-3.

11. Ibid., 5-6.

12. Ibid., 16,17 .

13. Ibid., 33.

14. Ibid., 46. 


\section{The Rice Institute Pamphlet}

15. Ibid., 68.

16. The Basic Teachings of Oomoto (Kameoka, Kyoto-fu, Japan: The Oomoto Headquarters, 1955), 44.

17. Ibid., 57-58.

18. This book is available with other literature from Seicho-no-Ie Foundation, Divine Publication Department, Tokyo, Japan.

19. Taniguchi, Divine Education and Spiritual Training of Mankind, 136.

20. Ibid., 137.

21. Ibid., 231-232.

22. Ibid., 235.

23. Ibid., 196-208.

\section{ChAPtER VI-PhILOSOPHY}

1. The best summary article is Gino Piovesana's "Main Trends of Contemporary Japanese Philosophy," Monumenta Nipponica, XI, 60-74. Father Piovesana spent a number of years collecting materials on the background of Japanese philosophy and knows contemporary developments from his own experience.

2. Ibid., 70 .

3. Ibid.

4. Matao Noda, "East-West Synthesis in Kitarō Nishida," Philosophy East and West, IV, 359.

5. Language, Meaning and Values (Tokyo: Waseda University Press, 1956), essays in philosophical analysis edited by Uyeda, contains a brief statement of his position. Cf." "A Tradition of Linguistic Analysis," 505.

6. T. Taketi, "Japanische Philosophie der Gegenwart," Blätter für Deutsche Philosophie, 1940, Heft 3, 277-299.

7. Piovesana, op. cit., 64. Only a small part of Nishida's work is available in a European language. Robert Schinzinger edited a German translation of Nishida's essays entitled, Die Intelligible Welt (Berlin: Walter de Gruyter, 1943).

8. Noda, op. cit., 350 .

9. Taketi, op. cit.

10. Koyama's, The Philosophy of Nishida (Tokyo: Iwanami, 1935) is a standard work on Nishida's thought. Taketi quotes from its argument at length.

11. Taketi, op. cit.

12. Noda, op. cit., 358-359.

13. Hiroshi Nagai, "Some Aspects of the Philosophy of Science in Japan," Annals of the Japan Association for Philosophy of Science, I, 78-79. 